\title{
Defining Dry Rivers as the Most Extreme Type of Non-Perennial Fluvial Ecosystems
}

\author{
María Rosario Vidal-Abarca *, Rosa Gómez, María Mar Sánchez-Montoya, María Isabel Arce, \\ Néstor Nicolás ${ }^{D}$ and María Luisa Suárez
}

Department of Ecology and Hydrology, Faculty of Biology, Campus of International Excellence “Campus mare Nostrum", University of Murcia, Campus de Espinardo, 30100 Murcia, Spain; rgomez@um.es (R.G.); marsanch@um.es (M.M.S.-M.); marisarce@um.es (M.I.A.); nestor.nicolas@um.es (N.N.); mlsuarez@um.es (M.L.S.)

* Correspondence: charyvag@um.es

Received: 30 July 2020; Accepted: 29 August 2020; Published: 3 September 2020

\begin{abstract}
We define Dry Rivers as those whose usual habitat in space and time are dry channels where surface water may interrupt dry conditions for hours or a few days, primarily after heavy rainfall events that are variable in time and that usually lead to flash floods, disconnected from groundwater and thereby unable to harbor aquatic life. Conceptually, Dry Rivers would represent the extreme of the hydrological continuum of increased flow interruption that typically characterizes the non-perennial rivers, thus being preceded by intermittent and ephemeral rivers that usually support longer wet phases, respectively. This paper aims to show that Dry Rivers are ecosystems in their own right given their distinct structural and functional characteristics compared to other non-perennial rivers due to prevalence of terrestrial conditions. We firstly reviewed the variety of definitions used to refer to these non-perennial rivers featured by a predominant dry phase with the aim of contextualizing Dry Rivers. Secondly, we analyzed existing knowledge on distribution, geophysical and hydrological features, biota and biogeochemical attributes that characterize Dry Rivers. We explored the capacity of Dry Rivers to provide ecosystem services and described main aspects of anthropogenic threats, management challenges and the conservation of these ecosystems. We applied an integrative approach that incorporates to the limnological perspective the terrestrial view, useful to gain a better understanding of Dry Rivers. Finally, we drew main conclusions where major knowledge gaps and research needs are also outlined. With this paper, we ultimately expect to put value in Dry Rivers as non-perennial rivers with their own ecological identity with significant roles in the landscape, biodiversity and nutrient cycles, and society; thus worthy to be considered, especially in the face of exacerbated hydrological drying in many rivers across the world.
\end{abstract}

Keywords: dry rivers; geophysical and hydrological features; Biota; biogeochemical processes; ecosystem services; threats and management

\section{Introduction}

Non-perennial rivers are characterized by the presence of a dry phase (i.e., when surface water is lacking) of variable duration and spatial extent. Compared with perennial rivers, they have been less studied [1-12], despite occurring in all continents and climates [13,14], and covering a large geographical extent [15].

Valuable knowledge on their hydrology and ecology has been achieved recently $[14,16-18]$ and highlights the dry phase as one of the main factors that shape their structure and functioning [6,19-22]. Drying is fundamental to shaping aquatic biodiversity by impacting some biological groups such as aquatic arthropods [23-26]. Besides, the tight influence of the terrestrial environment contributes to 
shape macro and microbial community structure, carbon and nutrient stocks [27,28], and biogeochemical aspects [29-31].

Dry phase is variable in temporal duration, spatial extent and predictability (e.g., $[11,32,33])$. While, in some rivers, it can be limited to $2-3$ months (or even less) throughout a year, dry phase occurs on scales of years in others (e.g., [34]). Furthermore, drying may involve complete riverbed desiccation or takes place as isolated pools [35].

The duration of dry phase is critical in the ecology and functioning of these rivers, thus, detailed information about their hydrology of non-perennial rivers is essential [33,36-40]. Nowadays, there is a consensus on the need for detailed hydrological information on dry phase to disentangle how drying affects the whole ecology of non-perennial rivers.

Hydrologists, ecologists and geomorphologists have generated a vast terminology in an attempt to classify the huge universe of non-perennial rivers into different types, according mainly to the hydrology and, in particular, to dry phase duration (see Table 1). However, the fact that standard and robust criteria to properly classify the different proposed typologies are lacking makes the existing ones operationally weak. The arbitrariness in the use of these diverse terminologies likely results in misleading knowledge about the ecology of specific types of non-perennial rivers. For example, some authors have coined the term 'IRES' - intermittent rivers and ephemeral streams (sensu [14]) to, in practice, distinguish between fluvial ecosystems exhibiting short and large dry phases, respectively. Yet, such distinction in the literature is not adequately addressed on occasions. Particularly, the use of the term 'ephemeral' is not always clear, as we can find descriptions with very different hydrological regimes (see Table 1). This is especially critical when rivers rarely experience wet conditions regimes but are included in the same category of those able to harbor an aquatic environment for some time.

This article aims to highlight the singularity of a specific type of non-perennial rivers where aquatic conditions are anomalous, which we denominated 'Dry Rivers' (hereafter, DRs). We pose that, conceptually, DRs would represent the extreme of the hydrological continuum of increased flow interruption that typically characterizes the non-perennial rivers, thus being preceded by intermittent and ephemeral rivers that usually support longer flowing and/or stagnant aquatic phases, respectively, as described in the literature (Table 1). According to that, we define DRs as those whose usual habitat in space and time are dry channels where surface water may interrupt dry conditions for hours or a few days, primarily after heavy rainfall events, that are variable in time and that usually lead to flash floods, disconnected from groundwater and thereby unable to harbor aquatic life. By providing this definition, we also pose that, within the universe of non-perennial rivers, DRs are the river-type that most suffers from "terrestrialization" process at temporal and spatial scales, thus comprising the clear example of similarity between dry riverbeds and soils as previously highlighted [29]. In our work, structure and function of DRs are discussed in the context of other non-perennial rivers (intermittent and ephemeral) with the objective of properly describing this specific type of ecosystem as well as highlighting their valuable and, in some instances, unique ecological role.

Table 1. The terminology used in scientific literature to define non-perennial rivers characterized by a dry phase dominating a wet phase. The words used by the different authors are highlighted in bold.

\begin{tabular}{ll}
\hline \multicolumn{1}{c}{ Definition } & References \\
\hline $\begin{array}{l}\text { Ephemeral washes are those watercourses that flow briefly in direct response to } \\
\text { precipitation and are distinguished from intermittent streams because they are always } \\
\text { above the phreatic level. }\end{array}$ & [1] \\
\hline The ephemeral river, entirely dependent upon desert storms for surface flow. & {$[41]$} \\
\hline Wadi: Course that only transports water a few hours after rain. & {$[42]$} \\
\hline $\begin{array}{l}\text { An ephemeral stream was one flowing only in direct response to precipitation; with } \\
\text { measurable discharge occurring less than 10\% of the time. }\end{array}$ & {$[43]$} \\
\hline $\begin{array}{l}\text { Ephemeral streams are apparent only after periods of high storm intensity or snow melts; } \\
\text { they seldom contain any animal or plant life. }\end{array}$ & [44] \\
\hline
\end{tabular}


Table 1. Cont.

\begin{tabular}{|c|c|}
\hline Definition & References \\
\hline $\begin{array}{l}\text { They distinguished 'temporary' or 'intermittent' rivers, with more-or-less regular, } \\
\text { seasonally intermittent discharge, from 'ephemeral' or 'episodic' rivers, which flow only } \\
\text { after unpredictable rainfall. }\end{array}$ & [45] \\
\hline $\begin{array}{l}\text { The author provided a definition based upon annual flow duration, distinguishing } \\
\text { ephemeral systems, flowing }<20 \% \text { of the year, from intermittent systems flowing } \\
\text { between } 20-80 \% \text { annually. }\end{array}$ & [46] \\
\hline $\begin{array}{l}\text { The episodic systems, restricted to arid and hyper-arid regions, contain water on an } \\
\text { unpredictable basis. The authors discouraged the use of the term ephemeral as a synonym } \\
\text { for episodic and the use of the term temporary as a synonym for intermittent. }\end{array}$ & [47] \\
\hline $\begin{array}{l}\text { Ephemeral: Rivers that flow for less time than they are dry. Flow or flood for short periods } \\
\text { of most years in a five-year period, in response to unpredictable high rainfall events. } \\
\text { Support a series of pools in parts of the channel. Episodic: Highly flashy systems that flow } \\
\text { or flood only in response to extreme rainfall events, usually high in their catchments. May } \\
\text { not flow in a five-year period or may flow only once in several years. }\end{array}$ & [11] \\
\hline $\begin{array}{l}\text { Term 'ephemeral' used by hydrogeologists to encompass running waters that are } \\
\text { permanently disconnected from the GWT (groundwater table), for example, dryland } \\
\text { rivers that flow only for a short period during and after rainstorms. }\end{array}$ & [48] \\
\hline $\begin{array}{l}\text { Ramblas can be dry for many years and only transport water for a few days as a result of } \\
\text { heavy rainfall. }\end{array}$ & [49] \\
\hline $\begin{array}{l}\text { Ephemeral (or episodic) streams are usually dry except for several days immediately } \\
\text { following precipitation. }\end{array}$ & [50] \\
\hline $\begin{array}{l}\text { Ephemeral (dry washes): A stream or portion of a stream which flows briefly in direct } \\
\text { response to precipitation in the immediate vicinity, and whose channel is, at all times, } \\
\text { above the groundwater reservoir. Ephemeral streams are unique in that they lack } \\
\text { permanent flow except in response to rainfall events. }\end{array}$ & [51] \\
\hline $\begin{array}{l}\text { Ephemeral freshwater systems (EFS). In the highest reaches of these segments, stream } \\
\text { flow is generally less than permanent. }\end{array}$ & [52] \\
\hline $\begin{array}{l}\text { Streams can be classified as perennial, flowing all the time or, at least at all times, except } \\
\text { extreme droughts; intermittent, flowing some of the time and receiving water from } \\
\text { groundwater; or ephemeral, flowing rarely and not receiving input from groundwater. } \\
\text { Ephemeral, not holding surface water most of the year. }\end{array}$ & [53] \\
\hline $\begin{array}{l}\text { Temporary systems cover those that are: ephemeral—ones which receive water for a short } \\
\text { period very occasionally and highly unpredictably; episodic—-those that fill occasionally, } \\
\text { and which may last months or even years. }\end{array}$ & [54] \\
\hline $\begin{array}{l}\text { Ephemeral streams are those that only flow during and in immediate response to } \\
\text { precipitation events. The groundwater table is situated below the streambed so that the } \\
\text { channel never receives groundwater discharge. Ephemeral streams are always losing } \\
\text { streams. }\end{array}$ & [55] \\
\hline $\begin{array}{l}\text { Intermittent (periodically dry, fed from seasonal flow) and ephemeral (periodically dry, } \\
\text { event-based flow) streams are predominantly located in the uppermost reaches of a } \\
\text { watershed. }\end{array}$ & [56] \\
\hline $\begin{array}{l}\text { Episodic-Ephemeral: Water flow and pools are short-lived and occasional. Most of the } \\
\text { organisms found are opportunistic, adapted to a quick development of their biological } \\
\text { cycle. Biological quality assessment needs other methods beyond the customary study of } \\
\text { aquatic fauna (e.g., desiccation-resistant stages of aquatic fauna or terrestrial fauna). }\end{array}$ & [57] \\
\hline The flow in ephemeral streams is episodic, with limited and stochastic water supply. & [58] \\
\hline $\begin{array}{l}\text { Episodic or ephemeral-those that flow and maintain water on a largely unpredictable } \\
\text { basis, depending on precipitation events, and with hydrological continuity for only a short } \\
\text { period of time (usually days to weeks). }\end{array}$ & [59] \\
\hline $\begin{array}{l}\text { The author use 'temporary' as a collective adjective to refer to all waterways that cease } \\
\text { surface flow at some points in time and space along their course, and 'ephemeral' for the } \\
\text { subset of temporary streams that flow only briefly (days to weeks), usually after rainfall } \\
\text { and runoff. }\end{array}$ & [60] \\
\hline
\end{tabular}


Table 1. Cont.

\begin{tabular}{lc}
\hline \multicolumn{1}{c}{ Definition } & References \\
\hline $\begin{array}{l}\text { The authors use the term intermittent rivers to refer to all temporary, ephemeral, } \\
\text { seasonal, and episodic streams and rivers in defined channels. }\end{array}$ & [32] \\
\hline $\begin{array}{l}\text { Ephemeral stream: Flow duration }<2 \text { months; Pool duration: variable; dry period: }>10 \\
\text { months/year. }\end{array}$ & [61] \\
\hline $\begin{array}{l}\text { Perennial and ephemeral streams constitute the limits of a continuum composed of a } \\
\text { multitude of intermediate flow regimes, which can be described in a different way. }\end{array}$ & [62] \\
\hline $\begin{array}{l}\text { Wadis are dynamic systems with hydrological regimes shifting between long periods of } \\
\text { drought and sudden flash flooding. }\end{array}$ & [63] \\
\hline $\begin{array}{l}\text { The term ephemeral implies a shorter flow duration and lower predictability than } \\
\text { intermittent but there are not fixed boundaries. }\end{array}$ & [64] \\
\hline
\end{tabular}

Overall, non-perennial rivers tend to be overlooked by society, water managers and ecologists, probably due to the prevalent lack of flow (e.g., $[65,66])$. Such overlooking is even more acute in DRs where the presence of water is merely anecdotic. Besides, the poor and disperse existing ecological knowledge on this type of ecosystem contributes to limit our decision making in conservation strategies.

In this article, we firstly reviewed the variety of definitions used to refer to non-perennial rivers to properly contextualize the DR type. Secondly, we analyzed existing knowledge on the distribution, geophysical and hydrological characteristics, biota and biogeochemical attributes in DRs. We also explored the capacity of DRs to provide ecosystem services and described major aspects of anthropogenic threats, management challenges and conservation of these ecosystems. We applied an integrative approach that incorporates to the limnological perspective the terrestrial viewpoint, the key to understanding these ecosystems [29] and undeniably needed to properly define and contextualize DRs. Finally, we identified major knowledge gaps and research needs to deal with DRs in future studies.

\section{Contextualization of Dry Rivers}

After a review of the definitions proposed by many authors to characterize non-perennial rivers, there seems to be a certain consensus in differentiating intermittent from ephemeral rivers. However, paradoxically, some authors put both river types under the same umbrella when describing their ecology and management. There is some consensus that temporary and seasonal rivers are synonymous with intermittent rivers (e.g., [45,47]), which are characterized by the presence of a dry phase in which surface flow may disappear any time throughout the year.

Definitions used by the different authors to characterize the ephemeral rivers are more diverse and debatable (Table 1). There seems to exist some agreement that ephemeral rivers only transport water flow after rains (e.g., [11,42,50,60]) and that they are usually disconnected from groundwater (e.g., $[1,48,51,53,55])$. Some authors limit their location either to the headwaters of the basins (e.g., [52,56] or to the deserts (e.g., [41]), ignoring the global character of the geographical occurrence of these ecosystems. Other authors quantify the residence time of surface flow in the ephemeral rivers (e.g., [43,46,61]) and others (e.g., [57]) incorporate the biological features of the communities of aquatic organisms that presumably live in ephemeral or episodic rivers. Yet, according to Williams [44], these rivers cannot harbor aquatic life. In addition, other terms such as wadis, ramblas, episodic rivers, dry land rivers or dry washes have been regionally coined to describe non-perennial rivers, normally in dry climatic areas (Table 1).

Faced with this confusing framework, our intention is to analyze and to describe main biogeophysical and functional features of DRs to properly characterize their own entity as a particular type of ecosystem within the continuum described by non-perennial rivers. To do that, we compare DRs with intermittent and ephemeral rivers. Based on the widespread consideration of both terms in the literature, in our analysis, we consider intermittent rivers as those rivers experiencing flowing periods longer than dry periods year-round. On the contrary, we understand the ephemeral rivers as 
those experiencing flowing periods shorter than dry periods throughout the year, with surface water present for some months. Taking intermittent and ephemeral rivers as a framework, DRs would be located in the hydrological extreme of the gradient (Figure 1), with surface water present only during hours or days, always dependent on the rainfall event and its intensity.
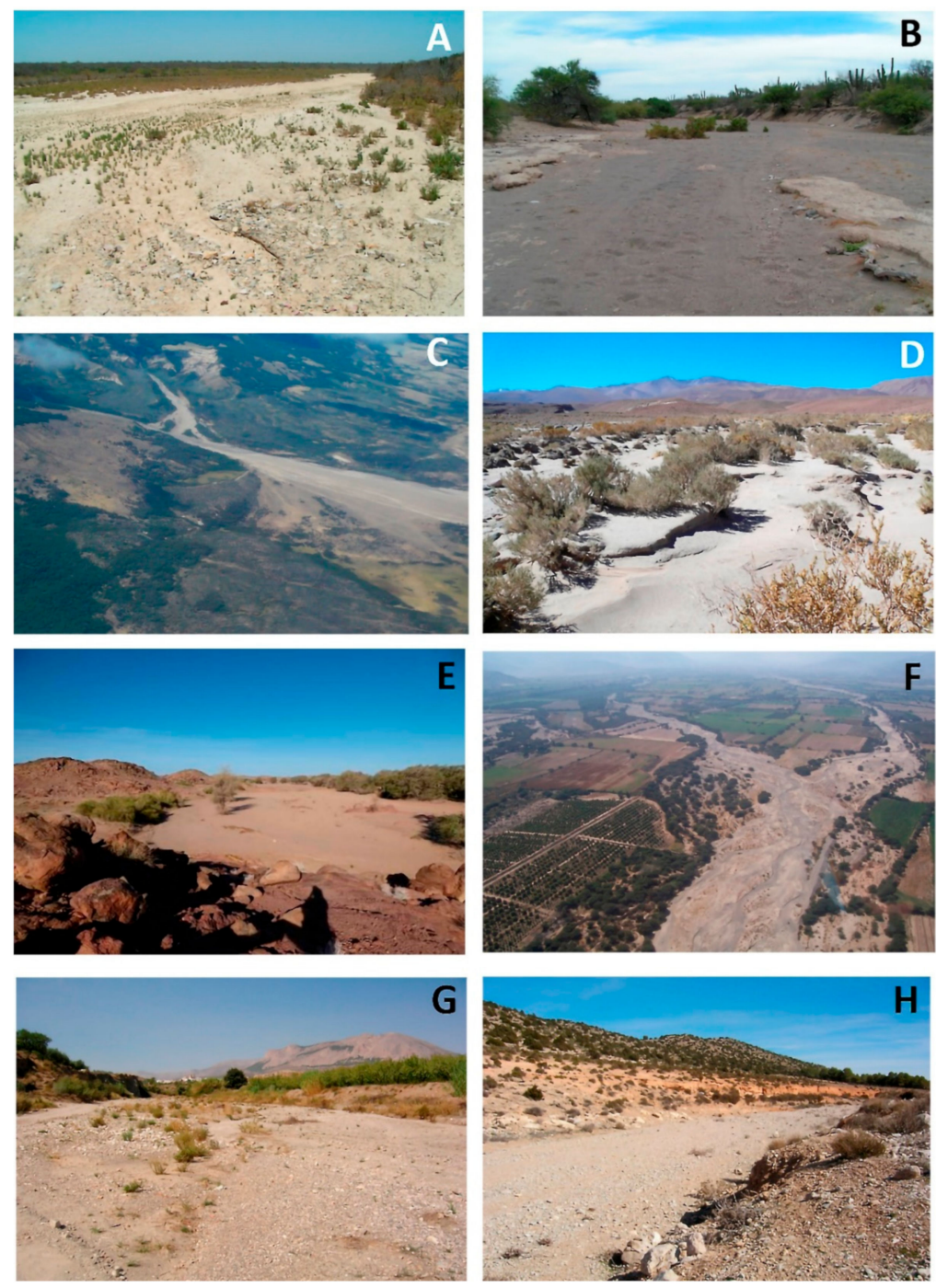

Figure 1. Examples of Dry Rivers worldwide. Ramblas Agua Blanca (A) and Cajete (B) in Baja California (Mexico); Dry River in Chilean Patagonia (C); Purifica River in the Atacama Desert (Chile) (D); Ugab River in Namibia (E); Dry River in Nazca (Perú) (F); Ramblas Chirivel (G) and Inazares (H) in southeast Spain.

\section{Distribution, Geophysical and Hydrological Characteristics of Dry Rivers}

DRs are found worldwide in different climatic areas (e.g., [32] (Figure 1)), although they dominate hyper-arid, arid and semi-arid lands (e.g., $[48,49,67]$ ), characterized by not only scarce rainfall (with long periods of zero precipitation; [68]), but also by high temperature and evapotranspiration rates. Although no global quantification of DRs on a worldwide scale is available, some data on the number of non-perennial rivers, including DRs, gives us an idea of the spatial magnitude of these ecosystems [15]. For example, Levick et al. [51] reported that between $94 \%$ (Arizona) and $66 \%$ (California) of the channels of southern U.S. exhibit flow interruption. For South Africa, Davies et al. [69] estimated that over $44 \%$ of the river length is non-perennial, and this is about $70 \%$ in Australia [70]. In the Mediterranean Region, more than half the rivers in Greece [16], and between $25-40 \%$ of the total length of rivers in France are intermittent [71]. Many Alpine, Arctic and Antarctic rivers are also non-perennial [32]. 
DRs include a wide range of ecosystems, from rivers featured by narrow channels, rocky beds, and steep slopes to rivers with wide sand beds and slight slopes. Despite being distributed worldwide, the presence of DRs is especially relevant in hyper-arid, arid and semi-arid areas.

From the geomorphological and hydrological viewpoints, DRs have differential characteristics to intermittent and ephemeral rivers (e.g., [2,4,7,12,72]). Depending on the slope, bigger amounts of sediment usually accumulate in DRs than in perennial and intermittent rivers (Figure 2), and there are two main reasons for this: (i) the erosive force of flash floods (e.g., [73,74]); (ii) a bigger supply of solid materials from the erosion of what are likely to be poorly vegetated hillslopes in arid lands [75]. It has also been pointed out that DRs produce bedload flux levels during floods that lie between 1 and 6 orders of magnitude more than in similar sized perennial rivers [75]. In addition, the morphology and stability of both channels and floodplains, and the sedimentation regime in DRs, depend almost exclusively on the frequency and intensity of flash floods (e.g., [76]) but also of bank cohesion and riparian vegetation characteristics (e.g., $[77,78])$. Indeed, the channel morphology can remain stable for many years until heavy floods erode and visibly modify the riverbed [79] (Figure 2). The channel geometry of DRs is a typical result of these unpredictable high-intensity events. Such events act as "pulses" and bring about abrupt changes by setting very wide channels [80] that constitute an adaptation of these rivers to both irregular surface water flow and the dynamics of the solid load transported during floods [73].

Likewise, sediments deposited in channels can remain immovable for decades until a high energy flood shifts them and transports them downstream (e.g., [73,75]), which are key for the morphological and dynamic development of DRs, as well as for the maintenance of riparian habitats.

The distribution of riverbed sediments in perennial rivers follows a typical longitudinal sequence from head to mouth: from coarse materials (bedrocks and gravel) in the upper zone to fine-grained materials (silt and clay) in lower zones [81]. However, in DRs, this longitudinal sequence from upstream to downstream is not so evident because flash flood events are faster and the deposition of the solid load transported over the channel bed occurs suddenly by intermixing sediments and materials of very variable sizes $[4,73]$. 


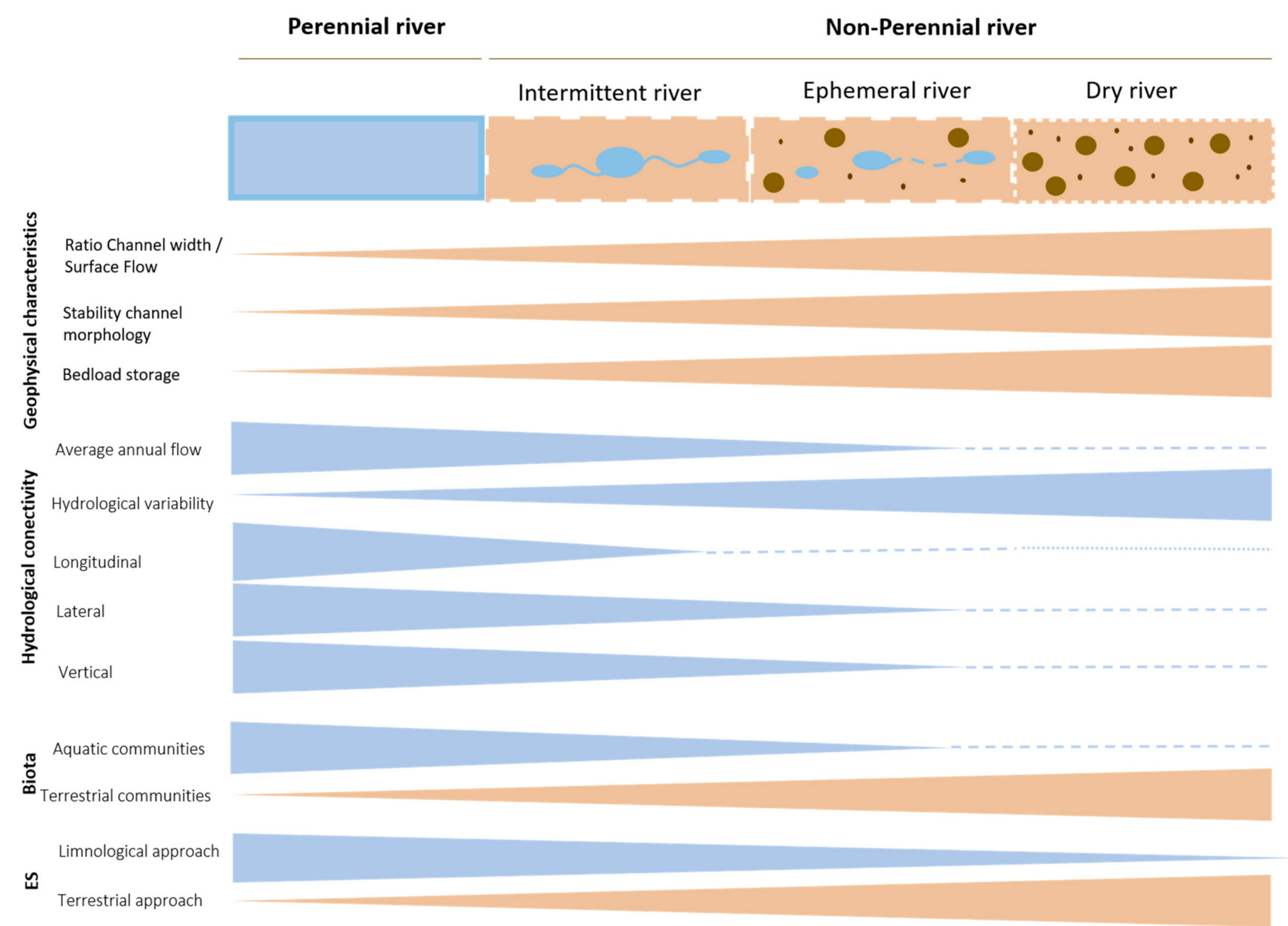

Figure 2. Differential relevance of main geophysical, hydrological and biological features of Dry Rivers with respect to perennial, intermittent and ephemeral rivers as well as of the approaches used to evaluate the ecosystem services (ES) they provide. The wider the bar is, the more relevant either the particular environmental feature or scientific approach is. Dashed and dotted lines indicate low relevance and total irrelevance, respectively, of a particular aspect. 
In hydrological terms, the almost complete lack of surface water flow with time and its common disconnection with groundwater are key hydrological features that distinguish DRs (Figure 2) from intermittent and some ephemeral rivers (e.g., [1,82]). The duration and extension of the surface water flow in any river generally depends on the alternation of water gains and losses controlled by flow at longitudinal (depending on the channel's geomorphological characteristics), lateral (depending on the channel's topography and substrate composition) and vertical (depending on the groundwater level) scale [83]. In intermittent rivers, the dry phase implies a temporal (several months a year) disconnection of channels in the longitudinal, lateral, and even vertical dimension. However, in DRs, such extraordinary hydrological connectivity remains practically null for years [34] (Figure 2) because they have no surface water flow for long periods [84]. Typically, in DRs, disconnection with the groundwater table is practically complete (e.g., [73,84]) and the flash flood events that could restore surface flow only last a few hours [85] (Figure 3). It is exclusively after these punctuated events when the entire drainage network is quickly, but poorly connected [86]. Graf [4] identified four flood types in rivers: flash floods, single-peak events, multiple-peak events, seasonal floods. The first two are the most common in DRs $[84,85]$ in which water flows very quickly. For example, the hydrographs of several flash floods in some DRs in southeast Spain are resolved in just a few hours (Figure 3).
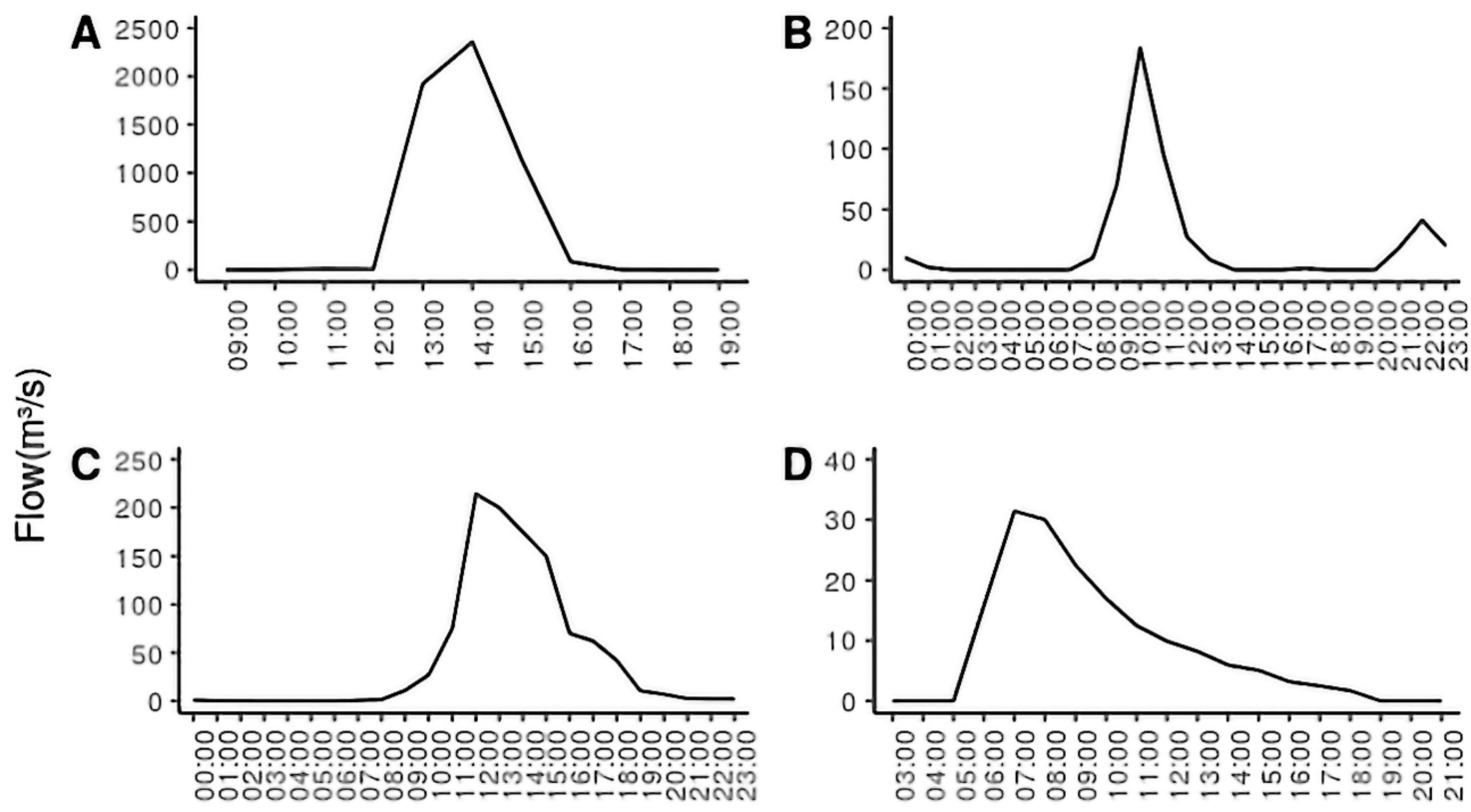

\section{TIme(hours)}

Figure 3. Hydrograph of flash floods in several Dry Rivers in southeast Spain. (A) Rambla de Benipila (23-24 October 2000); (B) Rambla de Benipila (28-29 September 2009); (C) Rambla de las Moreras (24 October 2000); (D) Rambla de Nogalte (28 September 2012).

Aside from these generalizations about the geophysical and hydrological features of the DRs, it should be noted the absence of current knowledge about the effects that climate change and aridification will have on the geomorphology of non-perennial rivers and, in particular, on DRs [87], which could modify the physical structure of these rivers (e.g., channel sinuosity, lateral stability, landform assemblages).

\section{Biota of Dry Rivers}

The dry phase dominating over the wet phase in DRs strongly shapes their biological communities, which are characterized by the presence of a diverse and abundant terrestrial biota rather than aquatic 
biota (Figure 2). The latter, if present, may be subject mainly to the presence of episodic isolated pools along dry channels.

In other types of non-perennial rivers, shorter dry periods prompt aquatic organisms (fauna, algae, vegetation) for certain adaptations to evolve, such as resistance (eggs and diapause) and resilience (dispersal) strategies to withstand drying (e.g., [33,88-90]). However, lack of surface water in DRs during such long periods may hamper the existence of even desiccation-resistant life states or "seed banks" in channel sediments or other refuges in rivers. Although it is known that some meiofauna taxa, like nematodes, can remain viable for decades as dormant eggs in dry sediments [91], it must be considered that as the dry period duration increases, resting eggs significantly decline (e.g., [88]) due to depleted energy reserves [92], decomposition by microorganisms [93] or predation [94]. In this context, understanding whether aquatic resistant forms can survive in DRs' sediments, and if they are capable of restoring the community of aquatic organisms in such a short wet phase (hours or days), are still critical gaps in DRs ecology.

Unlike aquatic invertebrates, terrestrial invertebrates can be a key biological component of DRs from ecological, functional and taxonomical perspectives as they benefit from the hardness of drying [95]. In fact, dry channels from different types of non-perennial rivers harbor diverse and unique terrestrial invertebrate assemblages across our planet [95-101], composed mainly of Formicidae, Araneae, Collembola and Coleoptera [95,97,98,100-102] (Figure 4).

In intermittent rivers, it was recently discovered that surface flow cessation and desiccation may enable the colonization of river channels by terrestrial invertebrates from adjacent riparian and upland habitats $[95,100]$. These dry channels provide temporary food subsidies from stranding aquatic organisms, such as fish, invertebrates and algae for terrestrial invertebrates (e.g., [3,21]). However, global knowledge is limited about the role of dry channels in DRs, characterized by lack of aquatic food resources (both stranding on dry channels and emerging aquatic insects) for the terrestrial ecosystem. A recent study in Namibia reported that channels in DRs harbored diverse and abundant terrestrial invertebrates despite the absence of aquatic subsidies [101]. The river channel invertebrate community was similarly diverse from those in riparian and upland areas, but composition differed from surrounding habitats, which evidenced the key role of dry channels in DRs contributing to the overall diversity in riverine landscapes. Channels of DRs could provide multiple ecological functions, similarly to intermittent and ephemeral rivers, probably offering more favorable biotic and abiotic environmental conditions than adjacent terrestrial habitats (Figure 4). For instance, channel of DRs may supply for terrestrial invertebrate terrestrial food subsidies (vegetation for herbivores and invertebrates for predators [101]), refuges from harsh environmental conditions (e.g., [98]), and act as mating sites (e.g., [103]) and dispersal corridors (e.g., [104,105]).

In addition, DRs also support a high diversity of terrestrial vertebrates like reptiles, birds and mammals (e.g., [51,106]). In fact, in hyper-arid and arid regions, these ecosystems have been defined as linear oases for fauna $[107,108]$, offering wetter conditions than the surrounding landscape [109]. Worldwide, DRs provide pivotal ecological functions for terrestrial vertebrates, which use these dry habitats as food resources, breeding and nesting sites, movement corridors, migration stopovers, and resting and shelter areas [106]. For instance, aardvarks (Orycteropus afer), a burrowing, insectivore and nocturnal mammal native of sub-Saharan Africa, excavates in DRs' channels to create burrows to live, breed and avoid high extreme temperatures and predators in the daytime [110] (Figure 4). The Mediterranean spur-thighed tortoise (Testudo graeca) selects sandy channels of DRs as nesting sites in SE Spain (J.D. Anadón; personal communication; Figure 4). In turn, some terrestrial vertebrates in DRs can play important ecological roles as landscape engineers, consumers and/or prey, seed dispersal agents and animal-mediated nutrient cyclers [106]. For instance, African elephants (Loxodonta africana), which dig water holes along dry channels, are an interesting example of landscape engineers (Figure 4). Although the presence of these water holes is limited to stretches with close groundwater, they can be of much ecological relevance for biota by providing water for themselves and for other wildlife [111], such as springbok, jackals and baboons [112]. 

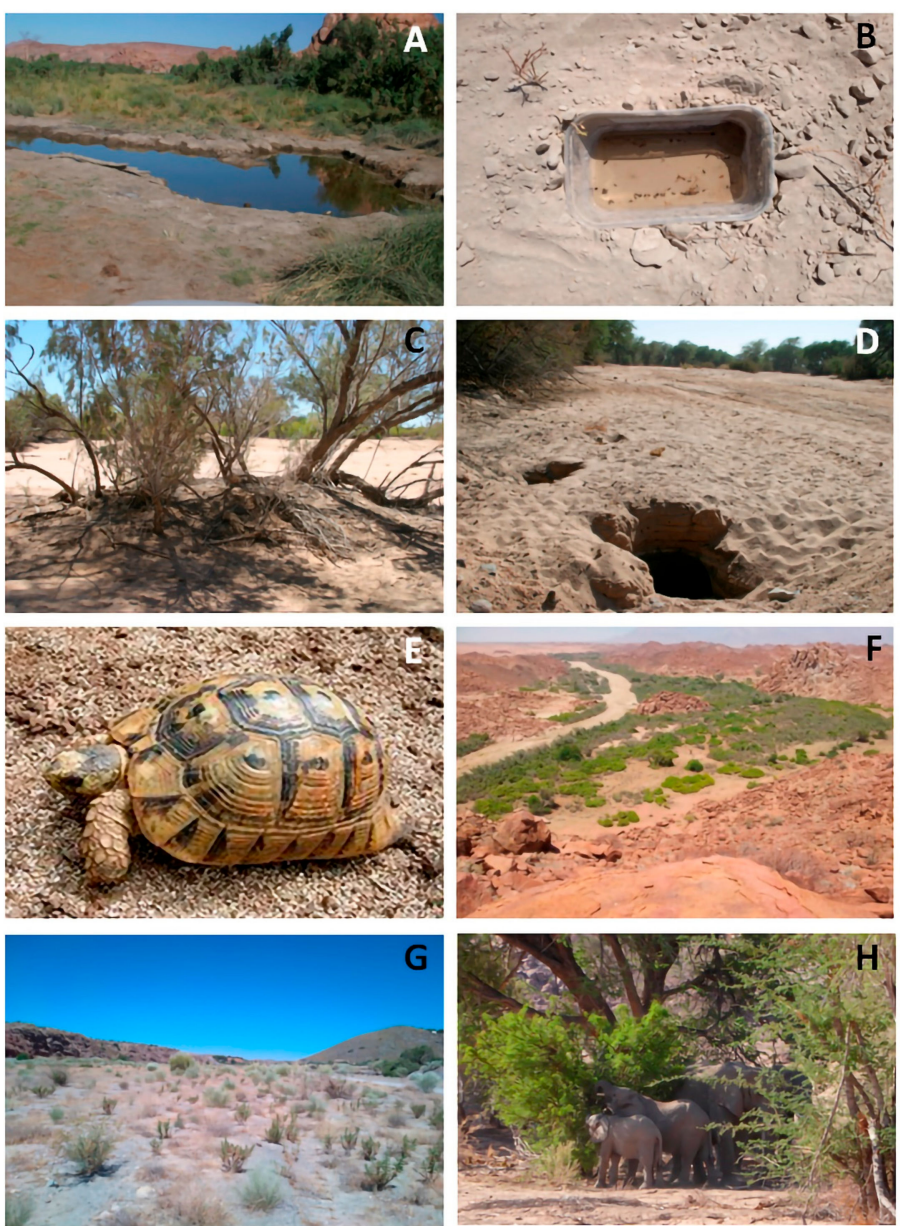

Figure 4. A water hole dug by elephants (Loxodonta africana) in the channel of a Dry River in Namibia (A); a pitfall trap in the channels of a Dry River in Spain containing terrestrial invertebrates (B); debris piles in the middle of a channel of a Dry River in Namibia (C); refuge created by an aardvark in the dry channel of a Dry River in Namibia (D); a Mediterranean spur-thighed tortoise (Testudo graeca) in Spain, which can select sandy channels of Dry Rivers as nesting sites (E); a Dry River in Namibia offering higher soil moisture and, consequently, more abundant vegetation compared to the surrounding dry landscape (F); terrestrial vegetation covering the channel of a Dry River in Spain (G); an elephant feeding on acacia trees in a Dry River in Namibia $(\mathbf{H})$.

Although some algae and aquatic plants can tolerate drying [113], DRs tend to be devoid of such aquatic biota due to harsh environmental conditions imposed by such a short wet phase (days or hours) and by the common disconnection with groundwater. DRs in arid and hyper-arid areas usually offer higher soil moisture and, consequently, more abundant vegetation than the surrounding dry landscape (e.g., $[17,114]$ ) (Figure 4). Channels of DRs can be covered by abundant terrestrial vegetation, such as helophytes, shrubs and trees (e.g., [78]) (Figure 4), which colonize from adjacent habitats (riparian and upland). Water availability is both a critical resource and a disruptive agent (if flash flood occurs) for vegetation in DRs, being these two factors responsible for their diversity [115]. The presence of vegetation along the channel can be the beginning of the formation of different depositional features, such as bars, banks and islands (e.g., [116]), with important geomorphological implications. Debris piles composed of wood, leaf litter and fruit frequently appear along channels of DRs (e.g., [8,101]), which are engendered by rare flood events that redistribute large amounts of organic matter along dry river channels $[9,117,118]$. These debris piles can, in turn, induce sediment deposition by contributing to the formation of a vegetated island, acting as nurseries for woody vegetation [9] (Figure 4), increasing environmental heterogeneity and resource availability. 
Terrestrial vegetation along DRs' channel may play a key role in structuring ground-dwelling arthropod communities, given the strong influence of vegetation on these communities [101,119]. For instance, the mentioned debris piles contribute to overall diversity by supporting a distinct terrestrial invertebrate community [101]. Additionally, vegetation stocks can be critical for terrestrial vertebrate fauna. This is the case of acacia trees along DRs' channels in Africa, as they comprise a vital food resource for large herbivores, such as elephants, giraffes, kudus, impalas, steenboks and other browsing ungulates (e.g., [106,120]).

\section{Biogeochemical Processing in Dry Rivers}

Ecosystem functioning in DRs is essentially governed by biogeochemical processes that occur in dry sediments. Due to the lack of surface water, dry channel sediments have been traditionally considered to be biogeochemically quiescent compared to running waters $[16,17]$. Consequently, dry riverbeds have been poorly included in fluvial research, and their potential contribution to global biogeochemical cycles has been neglected for years [29,31]. It was only very recently when dry channels of non-perennial rivers, including DRs, were recognized as being important habitats for nutrient and organic matter processing on landscapes [17,29-31,121-123].

Water is an ultimate resource for life and biotic reactions but is also critical as a solvent and transport medium of solutes, two roles that also regulate biogeochemical processes. In DRs, drought is pervasive along their course and over time, and lack of a regular disturbing water flow imprints structural and functional characteristics quite similar to soils, potentially much more noticeable if compared with intermittent and ephemeral rivers. For instance, sediment aggregates, presence of terrestrial plant species or leaf litter inputs from riparian zones confer the perfect physical frame that allows the colonization and development of typical biotic communities of soil habitats [29]. As in terrestrial habitats, fungal communities linked to the higher presence of lignin and cellulose compounds in material of a terrestrial origin [124] are expected to be important for organic matter dynamics in DRs. Yet, in intermittent and ephemeral rivers with desiccation periods relatively shorter, both organic resources and the microbial community in the dry phase may still be of aquatic origin, as, for instance, the biofilm patches described in several Mediterranean intermittent rivers during summer drought [125]. Additionally, the presence of aquatic vegetal biomass, like macrophytes, rarely applies to DRs, where most organic stocks covering the channel are of terrestrial origin. In fact, a recent global analysis of 212 dry channels across all continents has demonstrated the large amounts of terrestrial organic matter that dry channels accumulate, such as leaf litter and wood $(\sim 40 \%)$ [121]. Although that study did not explicitly point out DRs from other non-perennial rivers, its results suggest long dry periods and high aridity as important predictors that support terrestrial plant litter accumulation but also its decomposability. This and other works indeed suggest photodegradation may play an important role in organic matter decomposition rates in arid climates by facilitating its decomposability [126,127], which especially applies to DRs, that are mostly represented in dry-climatic areas. This is also important when large amounts of plant material of hard decomposability (e.g., Phagmites australis) cover the most part of the river channel, like occurring in SE Spain where a groundwater table often develops in DRs [29,49]. In other DRs, such as the Namib Desert, organic matter stocks in the form of debris piles (wood, leaf litter and fruit) have been reported to be essential for not only sediment fertility, but also as hot spots for microbial activity being key in ecosystem biogeochemistry [101]. The large amount of terrestrial organic matter that DRs usually support may be transported together with riverbed sediments in a down direction following extraordinary flood-flush events, and potentially impacts the biogeochemistry of downstream ecosystems; e.g., reservoirs, by modifying nutrient status and generating anoxia. This scenario has been well described in catchments dominated by intermittent rivers, where high peaks of nitrogen and phosphorus are usually recorded after seasonal floods ("first flush events") (e.g., [128,129]). Despite flood events being sporadic, similar results have been described in DRs (e.g., [130]). 
The activity of arthropods and mammals and their excrements may not only provide the ecosystem with a source of nutrients and carbon, but may also impact leaf litter decomposition rates [101]; an influence much more noticeable if compared to intermittent and ephemeral rivers where the influence of terrestrial animals is limited to their relatively shorter dry period.

Recent literature highlights the pivotal role of dry inland waters for the global carbon cycle $[30,31,123]$. Although these studies do not explicitly separate DRs in the results, their estimations support the active contribution of DRs, as dry inland waters, controlling global C fluxes. In large scale experiment covering $\sim 200$ dry riverbeds across different climates, von Schiller et al. [30] measured moderate microbial respiration rates within the range of those found in soils. In a similar large-scale approach, albeit in terms of carbon dioxide $\left(\mathrm{CO}_{2}\right)$ fluxes, Keller et al. [123] accounted that global estimates increases by $6 \%$ when considering the contribution of dry habitats, and they suggest that the favored oxygenation for microbial growth and gas diffusion in dry habitats may be behind such a significant role. Yet, if compared with uphill soils, the authors found lower $\mathrm{CO}_{2}$ fluxes rates which attributed to the general low degree of rooting and plant development supporting microbial respiration of fluvial sediments. Compared with intermittent and ephemeral rivers, DRs would potentially allow higher similarities with soils, yet there is not enough empirical information to support this fact. Nevertheless, despite potential similarities in carbon transformation rates and drivers, such biogeochemical processing in DRs must not be considered terrestrial but a critical component of the fluvial network that run dry most of the time [131,132].

Changes in aerobic reactions over anaerobic pathways that happen in dry habitats are especially interesting for the nitrogen cycle. Drying tends to drive progressive shifts in the relative importance of ammonia oxidation vs. denitrification in rivers [37,133] by favoring the abundance of ammonia oxidizers if compared to the total microbial community [39]. As a result, dry riverbeds have been proposed as being sources of nitrogen as they tend to accumulate nitrate $\left(\mathrm{NO}_{3}\right)$ that is potentially released upon rewetting $[37,134-136]$. Yet, when terrestrial plants dominate the river channel in DRs, the direct assimilation of $\mathrm{NO}_{3}$ into biomass may result in less $\mathrm{NO}_{3}$ storage in sediments compared to those from intermittent and ephemeral rivers. On the contrary, processes such as atmospheric deposition and $\mathrm{N}_{2}$ fixation by terrestrial plants may be more relevant in nitrogen cycling in DRs in time and space terms compared to intermittent rivers. Nevertheless, as described in soils, the contribution of these processes depends on both climate conditions (atmospheric pollution) and the degree of plant coverage and species composition in the channel [29].

As in soil, extreme drought in river sediment impacts the extent to which microbial reactions and nutrient transformation rates occur. Drought stresses all organisms and can potentially kill them or drive the evolution of dry-adapted life history strategies, e.g., accumulation of solutes in cells or maintenance of extracellular enzyme activity to cope with water stress [137]. Of course, drought ends after water arrives, leading that drying-rewetting phenomenon is always coupled in non-perennial river sediments. In intermittent and ephemeral rivers, desiccation effects usually end in response to seasonal flow resumption. Indeed, this scenario has inspired some concepts about non-perennial rivers' functioning. For example, the punctuated longitudinal biogeochemical reactor concept [16], which poses that non-perennial rivers present high and low biogeochemical rates in flowing and dry phases, respectively, refers mainly to their capabilities to transform riverbed particulate organic matter, but rarely applies to rivers that lack flowing phases. As in soils, in DRs, desiccation stress is susceptible to be mitigated sporadically upon any minor rewetting event. This is the key for maintaining the resistance and resilience of microbial communities in long dry phases [138], as well as for triggering microbial metabolism, and to mobilize carbon and nutrients at small-local scale, like in the form of $\mathrm{CO}_{2}$ emissions and leaching $\mathrm{NO}_{3}$ [30]. As biogeochemical processing under flowing conditions is not common in DRs, the implications of even small rainfall events on the whole ecosystem functioning is expected to be more significant in DRs if compared with other non-perennial rivers. For instance, short rainfall can be fundamental to shape redox and create anoxic habitats as well as to mobilize nutrients through sediments, conditions that cannot easily occur when humidity in sediments is very low. It is 
noteworthy that, unlike intermittent rivers, the functional implications of rewetting in DRs, primarily occur on a local scale-vertical and lateral, instead of at longitudinal scale associated with flow periods that only occur extraordinarily during flood events.

We must consider that DRs are included in the fluvial network and, although they do not look like "typical rivers" all year long, the magnitude and environmental drivers of how biogeochemical elements are transformed in them are critical aspects to be included in new arenas of research that help us to better understand the role of these ecosystems in global biogeochemical cycles.

\section{Ecosystem Services of Dry Rivers}

Ecosystem services (ES) have been defined as the benefits that people obtain directly and indirectly from nature $[139,140]$. This concept has recently been refined as nature's direct and indirect contributions to human well-being [141,142]. These contributions derive from the ecological functions of ecosystems, which are supported by the interaction of the biophysical structure of ecosystems (i.e., morphology, substrate type, material disposition, permeability, etc.), ecological processes (i.e., primary production, cycle of nutrients and organic matter decomposition) and the biodiversity they harbor (e.g., $[141,143])$.

In non-perennial rivers, the main elements that sustain ecological processes and functions are materials and nutrient inputs, substrate type and biodiversity, water and the biophysical structure of the channel [14,144]. Given the combination of hard environmental conditions in DRs (e.g., high insolation and air temperature), together with almost permanent absence of water, we could initially consider these rivers to provide fewer ES than intermittent and perennial rivers. However, this is only true from the limnological approach. Whereas aquatic elements play a more dominant role in ES production in perennial and intermittent rivers, terrestrial elements mostly determine the supply and maintenance of these services in DRs (Figure 2). For example, loss of food resources (e.g., fish) described in intermittent rivers in the dry phase, considered to be a negative impact of drying on ES [64], is replaced in DRs with terrestrial organisms that colonize their dry channels (e.g., rabbits, asparagus, etc. $[145,146]$. Likewise, the ecological functions mediated by aquatic biota, which are lost in the dry phase in intermittent rivers (e.g., bioremediation by microorganisms, algae, plants and animals), are performed by the terrestrial organisms (i.e., microbial, plants and animals) inhabiting DRs (e.g., [147]).

Different studies have evaluated the current status of the ES provided mainly by perennial rivers at regional (e.g., [148]), national (e.g., [149-152]) and international (e.g., [153-157]) scales. However, specific works that focus on ES in non-perennial rivers are missing, except for two recent studies that have analyzed the ES provided by IRES throughout their different hydrological phases (i.e., flow, non-flowing and loss of surface water) $[64,158]$. Both studies highlighted that fewer provisioning and regulating services and similar cultural services are provided in the dry phase of intermittent streams if compared to the other two hydrological states.

Here, we provide examples and scientific evidence of the ES provided by DRs based on a systematic literature review of the publications found on the ISI Web of Knowledge (see Supplementary Materials). Unlike previous studies, we found a similar number of ES in DRs to those provided by the flowing phase of IRES (Figure 5). Sixteen provisioning services were described by Datry and coauthors [64], provided by the flowing phase of IRES, and only two by the dry phase, as eight of them were altered and four had been lost, coupled with water loss. However, we identified thirteen provisioning services supplied by DRs (Figure 5; Supplementary Materials). In DRs, three provisioning ES, two of which were related to food production through aquaculture and others to animal-based resources, were not applicable because they were directly related to the permanent presence of water (see Supplementary Materials). The most important loss of ES occurred in regulating services (Figure 5). In the dry phase of IRES, and according to Datry et al. [64], all regulating services were either lost (6) or altered (14) (Figure 5). However, we found that the regulating services provided by the flowing phase of IRES and by DRs were similar (20 and 18, respectively) (Figure 5). For DRs, no evidence was found for either 
the noise buffering service or the visual impact mediated by the ecosystem, or the control of diseases and chemical condition of salt waters (see Supplementary Materials). Lack of scientific evidence for some of the ES potentially provided by DRs does not necessarily mean that these services do not exist, rather they have not yet been found. Finally, practically all cultural services were provided by both the hydrological phases of IRES and DRs (Figure 5).
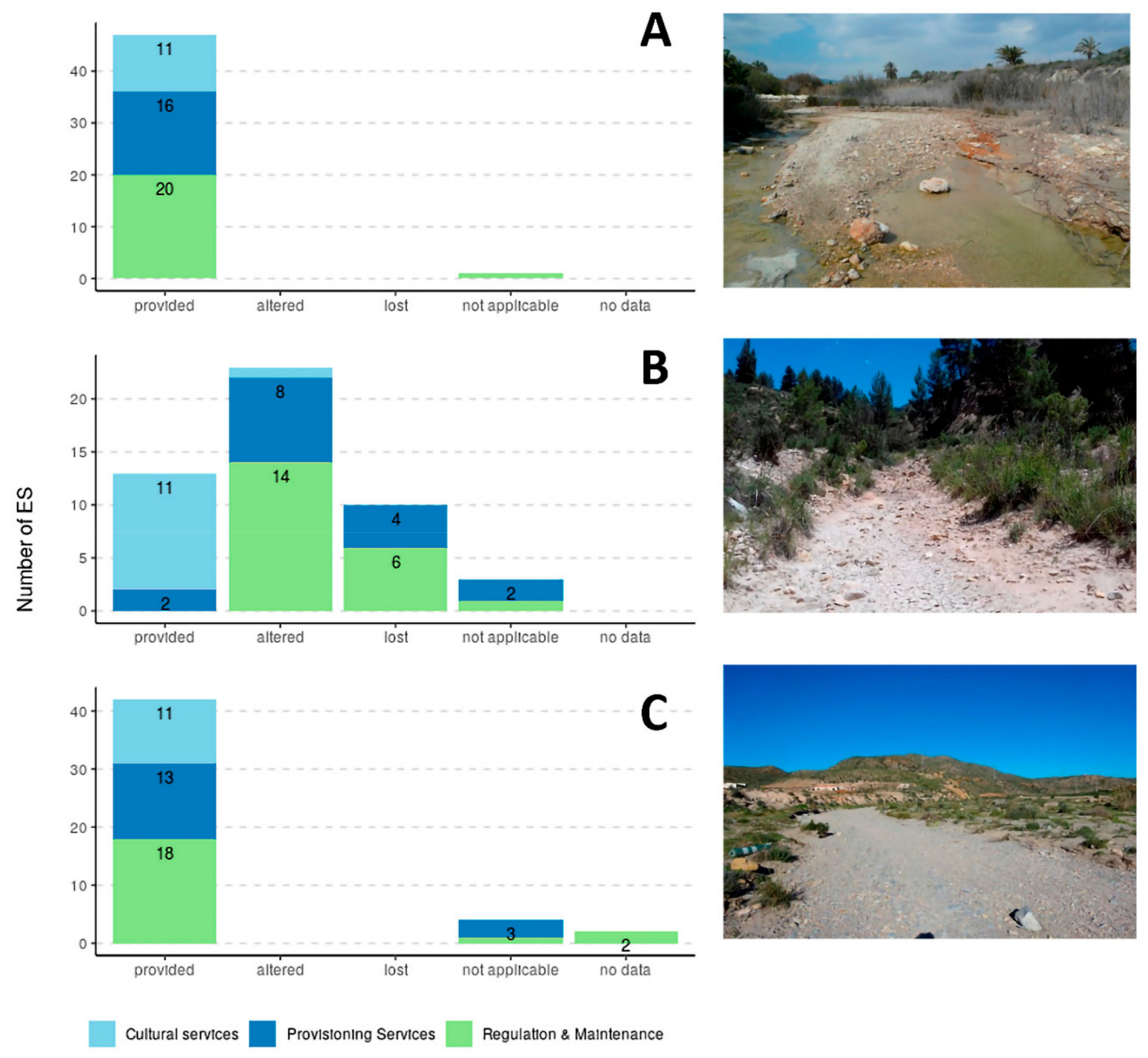

Figure 5. Histograms of the number of provisioning, regulating and cultural services presumably provided by the two extreme hydrological phases (flowing (A) and dry (B)) of IRES (intermittent rivers and ephemeral streams, according to Datry et al. [64], and by Dry Rivers (C). For a classification of ecosystem services, see Supplementary Materials. The categories "altered" and "lost" refer to the dry phase of the IRES. The "not applicable" category is required because in both Dry Rivers and the dry phase of IRES, some ES cannot be provided, and the category "no data" refers to the ES not verified in the bibliography.

Although DRs and intermittent rivers can produce the same number of ES from a terrestrial and aquatic approach respectively, the level of dependence of local human communities regarding some services could be different. Freshwater is the most valued provisioning service in DRs according to Koundouri et al. [158] because of its scarcity and relevance in supporting other services such as crop production and livestock maintenance. Droughts often compromise the co-produced services that support the social and economic well-being of the human communities that live around the DRs. In this way, the success of agricultural and livestock activities becomes extremely difficult 
and the risk remarkably high [8], especially where poverty rates are higher [159]. In this point, Iniesta-Arandia et al. [160] highlight the relevance of local ecological knowledge for the maintenance of human populations in arid and semi-arid watersheds, even in rural areas of industrialized countries. For instance, knowledge of systems to collect, store and distribute water efficiently, developed over generations (e.g., [161,162]), has become vital to human well-being and its survival. Taking everything into account, local knowledge on water, crop and livestock management could be more relevant to the human community survival in DRs than in intermittent and perennial rivers, where some components of human well-being could compromise, like income, but not survival.

Briefly as herein shown, DRs are able to provide a similar number of ES to the flow phase of the IRES, which resemble perennial rivers. This fact contributes to support the notion that DRs are often studied only from an aquatic perspective, where the presence or absence of surface water is the conditioning factor that explains why their functioning has been overlooked to date. In addition, scientists still need to learn more about DRs' ability to provide people with ES. In DRs, information on the "where" (spatial scale), "when" (temporal scale) and "how" ES are generated is scarce, and also about the role of flash floods in the reactivation and/or disorganization of the biophysical structure of the channels supporting the ecological functions which, in turn, maintain the supply of ES.

\section{Anthropogenic Threats to Dry Rivers}

DRs collect the main common human-related disturbances in fluvial (e.g., conduits for waste water disposal, dumping rubbish, groundwater withdrawal, channeling) and terrestrial ecosystems (e.g., road traffic and road construction, riverbed cultivation, livestock grazing, urbanization, camping and hiking, mining) likely because they are considered by society as useless ecosystems $[49,65,66]$. The poor recognition of DRs is paradoxically more evident in dry climatic areas despite being abundant, since here, any freshwater body aims to meet human demands and the concept of river management conservation is still strongly associated to the existence of water supply. Although the channel surface may remain dry for most of the year, DRs can support a volume of water stored beneath their channel. Thus, any attempt to capture, store or transfer water has negative effects on the ecosystem (e.g., [8]). All these factors ultimately place DRs as one of the most threatened fluvial ecosystems worldwide $[8,49,51,163]$.

DRs are subjected to considerable hydrological pressure with important negative socio-economic effects (e.g., $[163,164])$. Construction of dams to collect flooding waters in their upper sections likely leads to fewer flood events and groundwater recharge below dams, which bring about changes in the structure and distribution of streamside vegetation and forests with serious consequences for wildlife, habitat quality and channel morphology [8,165-167]. In addition, reduction of flood inputs plays a critical role in regulating organic matter transport and deposition, with consequences for primary and secondary production $[9,168]$. Flood modification affects the availability and structure of various microhabitats, such as debris piles and dry pools, which have been recently proven to be critical habitats in DRs [101]. Following floods, when the groundwater table stays only a few meters below the surface, people and animals gain access to groundwater by digging the riverbed [163]. Today, boreholes and pumps ensure year-long accessibility to water along DRs. However, a reduction in the water table caused by water extraction from aquifers, alters not only floodplain and riparian habitats, but also the vegetation and geomorphology of many DRs worldwide $[8,51,165]$.

On the other extreme, we find that DR channels are likely used to convey water for irrigation or for sewage water disposal from agricultural or urban uses by inducing perennial flow, similarly to what occurs in intermittent streams [169] (Figure 6). However, the natural prevalence of dry conditions in DRs means that these effects are even more harmful for ecosystem integrity compared to intermittent rivers. Due to the absence of water dilution capacity, the impact of sewage waters in channels are more noticeable in DRs. For example, wastewater inputs to ephemeral streams of Israel and Palestine have created the continuous flows and colonization of part of the active channel by vegetation with consequent habitat and channel morphology modifications [170]. In the Mediterranean Region, rapid 
agricultural developments have led to the large-scale conversion of natural areas into agricultural land, massive booms in reservoir and flood control constructions, and extensive water use for irrigation [171]. Building water derivation channels provides agriculture with water in regions where this resource is scarce, and drainage water from agricultural lands likely induces intermittent or even perennial flows in DRs.
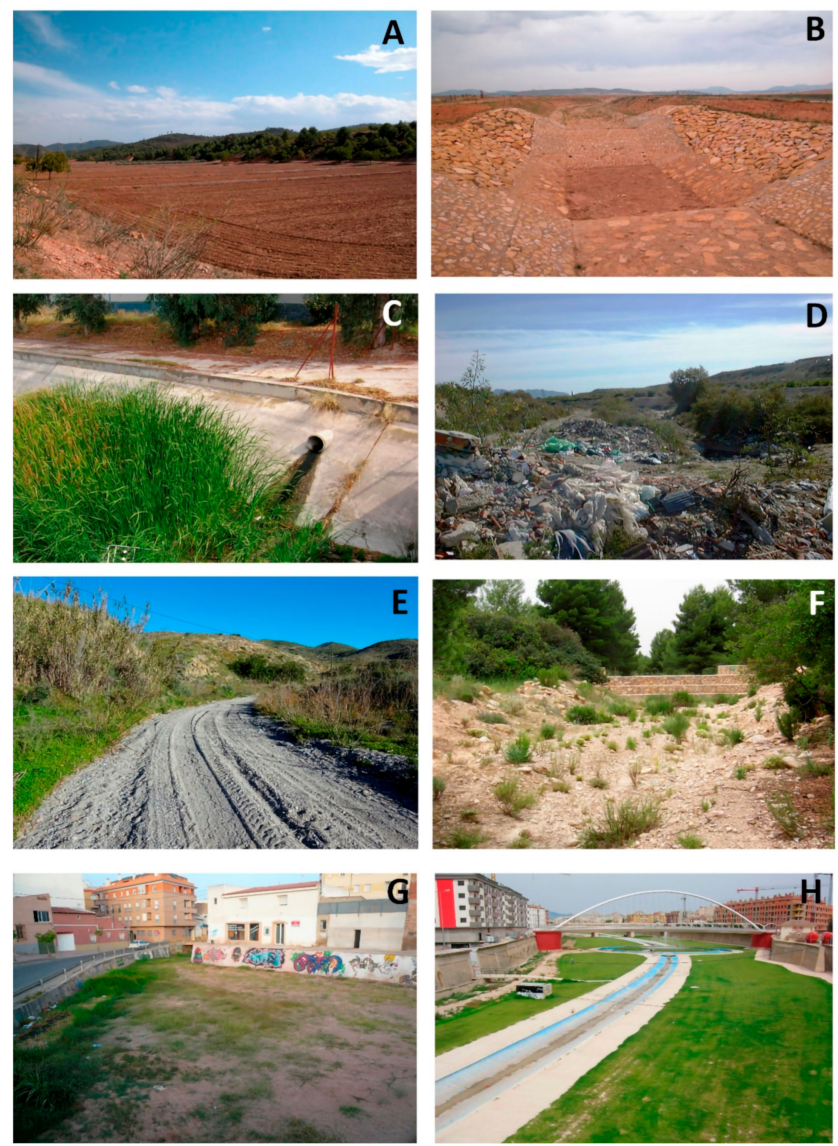

Figure 6. Different anthropogenic impacts on Dry Rivers. A dry riverbed prepared for cultivation (A); a channeled Dry River (B); a Dry River supporting aquatic vegetation as a consequence of the entry of a permanent wastewater effluent (C); a channel of a Dry River with rubble and rubbish (D); a channel of a Dry River used as a road (E); a small check-dam in a Dry River for sediment retention (F); a channeled urban Dry River (G); a completely transformed urban Dry River $(\mathbf{H})$.

Similarly, the physical alterations of dry channels are diverse and have complex and interactive effects. The regular absence of water in DRs means they become a target system for vehicular transport and road constructions, urbanization, solid waste disposal, sand and gravel extraction, and diverse outdoor activities (camping, hiking, etc.) (e.g., [51,163]) (Figure 6). Especially in arid regions, riparian areas of DRs support the vast majority of wildlife species, are predominant tree-growing sites and may represent areas of water supply (groundwater harvesting) that date back to ancient times $[8,51,163]$. These features make riparian areas attractive for humans, which in the United States has been described to lead to their alteration on a similar scale to that of wetland degradation [172].

Livestock grazing damage modifies riparian and riverbed vegetation and is one single albeit important factor in riparian ecosystem degradation in intermittent streams and DRs in southwestern North America [173]. Livestock grazing also alters DRs' substrate through compaction, rooting, pugging and livestock waste excretion [98,174]. It is likely that fertile sediments of DRs have been, and still are, used for agriculture, especially for intensive farming, as in SE Spain [49], where agricultural development has led to the many DRs disappearing from the landscape (Figure 6). Similarly, in southwestern North America, urban development is one of the main problems of land and 
ephemeral streams' network degradation [51]. In the Mediterranean Region, urbanization and DRs' bed occupation have become a commonplace practice for years with notably socio-economic costs because of flooding [175]. Sand mining in riverbeds leads to sediment deficits with notable effects on floodplains and river geomorphology, and can even destroy infrastructures like bridges and roads with their consequent economic costs. Certain functions of DRs, such as potential refuges for fauna (invertebrates and vertebrates) and biological corridors will, in turn, be negatively affected by all these physical alterations in DRs and their riparian habitats [106,176].

Finally, all these hydrological and physical alterations will ultimately favor species invasions with an important cascade effect for adjacent ecosystems, including aquatic and terrestrial habitats [177]. Globally, the most problematic invasive species in arid areas are phreatic, wetland or oasis specialists [178]. Their success is often linked with disturbance and is facilitated by agricultural activities, including water extraction, cropping and livestock management. The management of invasive alien plants in the arid parts of countries like South Africa is especially complicated by the cryptic and stochastic nature of the invasion process [178]. The colonization of DRs by the exotic and cosmopolitan herbaceous species, Arundo donax, is one of the consequences of their hydrological and riverbed alterations [179].

\section{Management Challenges}

Compared to perennial and intermittent streams, the question of managing and mitigating threats and impacts is even more complex in DRs. One reason is that they usually dominate in areas where water and resources are very scarce. In drylands, such as the Namib Desert [163], DRs enable the formation of permanent settlements, and facilitate sedentary livestock farming, irrigation, industry and tourism, among other human activities, because they function as riparian corridors and give the possibility of groundwater abstraction. Hence, a fine balance exists between benefits in the form of additional water and loss of alternative benefits (obtained by protecting DRs), which is also dependent on water existing. Appropriate management, therefore, strives for a proper balance among the water volumes entering the system, its natural water requirements and the human water demand. This is difficult to quantify and implement, particularly in arid environments, and especially in DRs with occasional aquifer recharge, while water abstraction and use are constant [163]. Hence, partnerships between agencies and institutions, coupled with the full participation of users that focus on integrated resource management must form part of the vision and management objectives for DRs. The results of such an approach would encompass enhanced livelihoods for those who depend on DRs' resources and their utilization [163]. Similarly, the incorporation of local knowledge (i.e., "knowledge co-production" [180]) about the management of these ecosystems' resources in environmental management programs is key to maintain the sustainable future of DRs. On the contrary, in developed countries where people do not closely depend on their services, DRs are not considered valued ecosystems. This underestimation likely extends to society as a whole, including most managers and technicians from regional and national governments. It also represents one of the main threats against the protection of DRs. Perhaps one of the main obstacles towards an effective conservation strategy is that the threats to ES that DRs provide are scarcely recognized and documented (e.g., [66]). In these cases, dissemination activities for citizens, designed to promote an overall appreciation for scientific knowledge and processes in DRs, could help to bring society closer to these ecosystems, which would ultimately affect their conservation positively.

As nature-based tourism grows, its impacts on aquatic ecosystems usually increase [181] and DRs are no exception, especially in those areas of special touristic interest (Namib Desert, the arid American southwest, Australia, etc. [8,51]), which require effective management techniques to conserve the integrity of DRs.

In many countries, the conservation and management of fluvial ecosystems require international legislation, such as the EU Water Framework Directive (WFD) and the U.S. Clean Water Act, based mostly on the monitoring of physico-chemical and biological elements to assess rivers' ecological 
quality. Lack of monitoring elements for DRs should be noted. Indeed, only recently, non-aquatic indicators have started being considered in rivers [182]. Terrestrial invertebrates as alternative biological indicators have been recently implemented as bioindicators by the Queensland Government's River Health Assessment Programme in intermittent rivers [98], yet their use is still in progress in Europe (e.g., [176]). In addition, some geomorphological indices have been ultimately developed for DRs (e.g., [183-185]). Similarly, physico-chemical features of dry sediments can be considered potential indicators of the ecological quality of DRs, nonetheless, this aspect requires future research.

DRs should not be considered from the entire watershed in an isolated manner but must be properly monitored following an integrative landscape view to detect impacts and design conservation strategies. For this purpose, the ecological assessment for DRs must explicitly consider their unique hydrological regime. Therefore, it is crucial to include new indices that integrate a terrestrial perspective.

\section{Conclusions}

Fluvial ecological research has traditionally considered non-perennial rivers from a limnological point of view by focusing mainly on aquatic and transitional states but has ignored the dry phase and neglected the importance of the terrestrial perspective to understand these rivers' ecology and functioning. By extension, DRs that mostly run dry have received, in practice, null attention. Furthermore, the complex and wide terminology used by different authors to refer to different types of non-perennial rivers seems to contribute to an inappropriate differentiation of DRs. Although surface water is only present in DRs for short periods (days or hours) and dry channels emerge as dominant habitats, our work outlines that DRs harbor and sustain diverse and abundant fauna and vegetation, are very active in the biogeochemical processing of nutrients and organic matter, and provide numerous and important ES. Compared to other non-perennial rivers, biodiversity, ecological processes, functions and ES provided by DRs are determined mainly by the long-lasting absence of surface water in space and time terms that is interrupted and shaped by sporadic and short rainfall events. When present, floods are responsible not only of DRs' channel dynamic and geomorphology but also represent a pulses' resource subsidy of energy and matter. Importantly, this work reinforces the idea that compared to the aquatic component, the terrestrial component clearly dominates in DRs and greatly defines the whole ecosystem through their functioning. Nevertheless, we must keep in mind that DRs are rivers and, therefore, integrated into the river network. So, they must be seen to form part of the fluvial system of a specific area and be included in ecological studies conducted on a global scale.

DRs are poorly valued ecosystems by society as a whole, as well as water managers and ecologists, who tend to associate ecological values of rivers with the presence of water. As a result, they are subjected to many hydrological and physical anthropogenic pressures that may severely impact biological communities, ecological processes and habitat quality. Monitoring programs that assess the ecological status of DRs, and environmental education and awareness programs, will contribute to safeguard their valuable aspects and to ensure a necessary change in perception. In this way, management policies should perform actions to ensure the ecological values of DRs and their contributions to human well-being, especially in the current climate change context, because the number of DRs is expected to increase [87].

Major knowledge gaps, with profound implications for conservation, remain in their hydrology (e.g., interannual variations, role of floods), biota (e.g., persistence of aquatic-resistant forms), biogeochemical (e.g., magnitude and environmental drivers of how biogeochemical elements are transformed in dry sediments) and ES (e.g., effect of drivers of change). A multidisciplinary perspective that combines earth sciences (ecology, soil science, climatology, hydrology, etc.) and social sciences (sociology, economic, anthropology, psychology, etc.) would allow us to approach, from a more integrative perspective, the world of DRs.

Supplementary Materials: The following are available online at http://www.mdpi.com/2071-1050/12/17/7202/s1. 
Author Contributions: M.R.V.-A. and M.L.S. conceived the original idea and structure of the manuscript and assumed the responsibility of the overall development. M.R.V.-A. and M.L.S. were responsible for the Sections 2 and 3, M.M.S.-M. leaded the Section 4, M.I.A. leaded the Section 5, N.N. leaded the Section 6 and R.G. was responsible for the Sections 7 and 8. M.R.V.-A., M.M.S.-M. and N.N. were responsible for the art work. All authors contributed to the revising draft versions of the whole manuscript. All authors have read and agreed to the published version of the manuscript.

Funding: This research has been financially supported by the Spanish Ministry of Economy, Industry and Competitiveness (project ref: CGL2017-84625-C2-2-R), the Spanish Ministry of Science, Innovation and Universities (project: RTI2018-097950-B-C22), FEDER (Fondo Europeo de Desarrollo Regional) and the Seneca Foundation (project: 20645/JLI/18).

Acknowledgments: N.N. was supported by a pre-doctoral grant from the Seneca Foundation (Science and Technology Agency of the Region of Murcia, Spain). M.I.A was supported by the "Juan de Cierva" postdoctoral program funded by the Spanish Ministry of Science, Innovation and Universities (Ref: IJC2018-036969-I). We also thank Helen Warburton for revising the English.

Conflicts of Interest: The authors declare no conflict of interest.

\section{References}

1. Leopold, L.B.; Miller, J.P. Ephemeral Streams—Hydraulic Factors and Their Relation to the Drainage Net; United States Geological Survey Professional Paper 282; U.S Government Printing Office: Washington, DC, USA, 1956.

2. Rodier, J.A. Aspects of arid zones hydrology. In Facets of Hydrology; Rodda, J.C., Ed.; John Wiley \& Sons: Chichester, UK, 1985; Volume II, pp. 205-247.

3. Boulton, A.J.; Suter, P. Ecology of temporary streams-An Australian perspective. In Limnology in Australia; De Deckker, P., Williams, W.D., Eds.; CSIRO 61: Melbourne, Australia, 1986; pp. 313-327. [CrossRef]

4. Graf, W.J. Fluvial Processes in Dryland Rivers; Springer: Berlin/Heidelberg, Germany; Verlag: Zurich, Switzerland, 1988.

5. Grimm, N.B.; Valett, H.M.; Stanley, E.H.; Fisher, S.G. Contribution of the hyporheic zone to stability of an arid-land stream. Verh. Intern. Ver. Limnol. 1991, 24, 1595-1599. [CrossRef]

6. Stanley, E.H.; Buschman, D.L.; Boulton, A.J.; Grimm, N.B.; Fisher, S.G. Invertebrate resistance and resilience to intermittency in a desert stream. Am. Midl. Nat. 1994, 131, 288-300. [CrossRef]

7. Thornes, J.B. Channel processes, evolution and history. In Geomorphology of Desert Environments; Abrahams, A.D., Parsons, A.J., Eds.; Chapman \& Hall: London, UK, 1994; pp. 288-317.

8. Jacobson, P.J.; Jacobson, K.M.; Seely, M.K. Ephemeral Rivers and Their Catchments: Sustaining People and Development in Western Namibia; Desert Research Foundation of Namibia: Windhoek, Namibia, 1995.

9. Jacobson, P.J.; Jacobson, K.M.; Angermeier, P.L.; Cherry, D.S. Transport, retention and ecological significance of woody debris within a large ephemeral river. J. N Am. Benthol. Soc. 1999, 18, 429-444. [CrossRef]

10. Giller, P.S. Floods and droughts: The effects of variations in water flow on streams and rivers. In Disturbance and Recovery of Ecological Systems: Proceedings of a Seminar Held on 14-15 February 1995; Myers, A.A., Giller, P.S., Eds.; Royal Irish Academy: Dublin, Ireland, 1996; pp. 1-19.

11. Uys, M.C.; O'Keeffe, J.H. Simple words and fuzzy zones: Early directions for temporary river research in South Africa. Environ. Manag 1997, 21, 517-531. [CrossRef]

12. Reid, I.; Frostick, L.E. Channel form flows and sediments in deserts. In Arid Zone Geomorphology: Process, Form and Change in Drylands, 2nd ed.; John Wiley \& Sons: Chichester, UK, 1997; pp. 205-219.

13. Costigan, K.H.; Jaeger, K.L.; Goss, C.W.; Fritz, K.M.; Goebel, P.C. Understanding control of flow permanence in intermittent rivers to aid ecological research: Integrating meteorology, geology and land cover. Ecohydrology 2016, 9, 1141-1153. [CrossRef]

14. Datry, T.; Bonada, N.; Boulton, A. Intermittent rivers and ephemeral streams. Ecology and Management; Academic Press: London, UK, 2017.

15. Raymond, P.A.; Hartmann, J.; Lauerwald, R.; Sobek, S.; McDonald, C.; Hoover, M.; Butman, D.; Striegl, R.; Mayorga, E.; Humborg, C.; et al. Global carbon dioxide emissions from inland waters. Nature 2013, 503, 355-359. [CrossRef]

16. Larned, S.T.; Datry, T.; Arscott, D.B.; Tockner, K. Emerging concepts in temporary-river ecology. Freshw. Biol. 2010, 55, 717-738. [CrossRef] 
17. Steward, A.L.; von Schiller, D.; Tockner, K.; Marshall, J.C.; Bunn, S.E. When the river runs dry: Human and ecological values of dry riverbeds. Front. Ecol Environ. 2012, 10, 202-209. [CrossRef]

18. Acuña, V.; Datry, T.; Marshall, J.; Barceló, D.; Dahm, C.N.; Ginebreda, A.; McGregor, G.; Sabater, S.; Tockner, K.; Palmer, M.A. Why should we care about temporary waterways? Science 2014, 343, 1080-1081. [CrossRef]

19. Vidal-Abarca, M.R. Los ríos de las cuencas áridas y semiáridas: Una perspectiva comparativa y de síntesis. Sci. Gerund. 1990, 16, 219-228.

20. Dent, C.L.; Grimm, N.B. Spatial heterogeneity of stream water nutrient concentrations over successional time. Ecology 1999, 80, 2283-2298. [CrossRef]

21. Lake, P.S. Ecological effects of perturbation by drought in flowing waters. Freshw. Biol. 2003, 48, 1161-1172. [CrossRef]

22. Vidal-Abarca, M.R.; Gómez, R.; Suárez, M.L. Los ríos de las regiones semiáridas. Ecosistemas $2004,13$. Available online: https://www.redalyc.org/articulo.oa?id=54013113 (accessed on 27 March 2020).

23. Bonada, N.; Rieradevall, M.; Prat, N. Macroinvertebrate community structure and biological traits related to flow permanence in a Mediterranean river network. Hydrobiologia 2007, 589, 91-106. [CrossRef]

24. Sánchez-Montoya, M.M.; Puntí, T.; Suárez, M.L.; Vidal-Abarca, M.R.; Rieradevall, M.; Poquet, J.M.; Zamora, C.; Robles, S.; Álvarez, M.; Alba, J.; et al. Concordance between ecotypes and macroinvertebrate assemblages in Mediterranean streams. Freshw. Biol. 2007, 52, 2240-2255. [CrossRef]

25. Leigh, C.; Datry, T. Drying as a primary hydrological determinant of biodiversity in river systems: A broad-scale analisis. Ecography 2016, 39, 001-013. [CrossRef]

26. Soria, M.; Leigh, C.; Datry, T.; Bini, L.M.; Bonada, N. Biodiversity in perennial and intermittent rivers: A meta-analysis. Oikos 2017, 126, 1078-1089. [CrossRef]

27. Bunn, S.E.; Balcombe, S.R.; Davies, P.M.; Fellows, C.S.; Mc Kenzie-Smith, F.J. Aquatic productivity and food webs of desert river ecosystems. In Ecology of Desert Rivers; Kingsford, R.T., Ed.; Cambridge 490; Cambridge University Press: Cambridge, UK, 2006; pp. 76-99.

28. Bernal, S.; von Schiller, D.; Sabater, F.; Martí, E. Hydrological extremes modulate nutrient dynamics in mediterranean climate streams across different spatial scales. Hydrobiologia 2013, 719, 21-42. [CrossRef]

29. Arce, M.I.; Mendoza-Lera, C.; Almagro, M.; Catalan, N.; Romani, A.M.; Marti, E.; Gomez, R.; Bernal, S.; Foulquier, A.; Mutz, M.; et al. A conceptual framework for understanding the biogeochemistry of dry riverbeds through the lens of soil science. Earth-Sci. Rev. 2019, 188, 441-453. [CrossRef]

30. Von Schiller, D.; Datry, T.; Corti, R.; Foulquier, A.; Tockner, K.; Marcé, R.; García-Baquero, G.; Odriozola, I.; Obrador, B.; Elosegi, A.; et al. Sediment respiration pulses in intermittent rivers and ephemeral streams. Glob. Biogeochem. Cycles 2019, 33, 1251-1263. [CrossRef]

31. Marcé, R.; Obrador, B.; Gómez-Gener, L.; Catalán, N.; Koschorreck, M.; Arce, M.I.; Singere, G.; von Schiller, D. Emissions from dry inland waters are a blind spot in the global carbon cycle. Earth-Sci. Rev. 2019, 188, 240-248. [CrossRef]

32. Datry, T.; Larned, S.T.; Tockner, K. Intermittent rivers: A challenge for freshwater ecology. Bioscience 2014, 64, 229-235. [CrossRef]

33. Sánchez-Montoya, M.M.; von Schiller, D.; Barbera, G.G.; Diaz, A.M.; Arce, M.I.; del Campo, R.; Tockner, K. Understanding the effects of predictability, duration, and spatial pattern of drying on benthic invertebrate assemblages in two contrasting intermittent streams. PLoS ONE 2018, 13, e0193933. [CrossRef] [PubMed]

34. Gordon, N.D.; McMahon, T.A.; Finlayson, B.L.; Gippel, C.J.; Nathan, R.J. Stream Hydrology: An Introduction for Ecologists, 2nd ed.; Wiley: Chichester, UK, 2004.

35. Stanley, E.H.; Fisher, S.G.; Grimm, N.B. Ecosystem expansion and contraction in streams. Bioscience 1997, 47, 427-435. [CrossRef]

36. Datry, T. Benthic and hyporheic invertebrate assemblages along a flow intermittence gradient: Effects of duration of dry events. Freshw. Biol. 2012, 57, 563-574. [CrossRef]

37. Gómez, R.; Arce, M.I.; Sánchez, J.J.; Sánchez-Montoya, M.M. The effects of drying on sediment nitrogen content in a Mediterranean intermittent stream: A microcosms study. Hydrobiologia 2012, 679, 43-59. [CrossRef]

38. Bogan, M.T.; Boersma, K.S.; Lytle, D.A. Resistance and resilience of invertebrate communities to seasonal and supraseasonal drought in arid-land headwater streams. Freshw. Biol. 2015, 60, 2547-2558. [CrossRef] 
39. Arce, M.I.; von Schiller, D.; Bengtsson, M.M.; Hinze, C.; Jung, H.; Eloy Alves, R.J.; Urich, T.; Singer, G. Drying and rainfall shape the structure and functioning of nitrifying microbial communities in riverbed sediments. Front. Microbiol. 2018, 9, 2794. [CrossRef]

40. Colls, M.; Timoner, X.; Font, C.; Sabater, S.; Acuña, V. Effects of duration, frequency, and severity of the non-flow period on stream biofilm metabolism. Ecosystems 2019, 22, 1393-1405. [CrossRef]

41. Mabbutt, J.A. Desert Landforms; MIT Press: Cambridge, UK, 1977.

42. Le Houérou, H.N. North Africa. In Aridland Ecosystems: Structure, Functioning and Management; Goodalld, W., Perryr, A., Eds.; Cambridge University Press: Cambridge, UK, 1979.

43. Hedman, E.R.; Osterkamp, W.R. Streamflow Characteristics Related to Channel Geometry of Streams in Western United States; U.S. Geological Survey Water-Supply Paper; USGPO: Washington, DC, USA, 1982; Volume 2193, pp. 1-17.

44. Williams, D.D. The Ecology of Temporary Waters; Croom Helm: New South Wales, Australia, 1987.

45. Boulton, A.J.; Lake, P.S. Australian temporary streams-Some ecological characteristics. Verh Intern. Ver. Theor. Angew. Limnol. 1988, 23, 1380-1383. [CrossRef]

46. Matthews, W.J. North American prairie streams as systems for ecological study. J. N. Am. Benthol. Soc. 1988, 7, 387-409. [CrossRef]

47. Comin, F.A.; Williams, W.D. Parched continents: Our common future? In Limnology Now: A Paradigm of Planetary Problems; Margalef, R., Ed.; Elsevier: Amsterdam, The Netherlands, 1994; pp. 473-527.

48. Bull, L.J.; Kirkby, M.J. Dryland river characteristics and concept. In Dryland Rivers: Hydrology and Geomorphology of the Semi-Arid Channels; Bull, L.J., Kirkby, M.J., Eds.; John Wiley \& Sons: Chichester, UK, 2002; pp. 3-15.

49. Gómez, R.; Hurtado, I.; Suárez, M.L.; Vidal-Abarca, M.R. Ramblas in south-east Spain: Threatened and valuable ecosystems. Aquat. Conserv. 2005, 15, 387-402. [CrossRef]

50. Fritz, K.M.; Johnson, B.R.; Walters, D.M. Field Operations Manual for Assessing the Hydrologic Permanence and Ecological Condition of Headwater Streams; EPA/600/R-06/126; U.S. Environmental Protection Agency, Office of Research and Development: Washington, DC, USA, 2006. [CrossRef]

51. Levick, L.R.; Goodrich, D.C.; Hernandez, M.; Fonseca, J.; Semmens, D.J.; Stromberg, J.C.; Leidy, R.; Scianni, M.; Guertin, D.P.; Tluczek, M.; et al. The Ecological and Hydrological Significance of Ephemeral and Intermittent Streams in the Arid and Semi-Arid American Southwest; US Environmental Protection Agency, Office of Research and Development: Washington, DC, USA, 2008.

52. Brooks, R.T. Potential impacts of global climate change on the hydrology and ecology of ephemeral freshwater systems of the forests of the northeastern United States. Clim. Chang. 2009, 95, 469-483. [CrossRef]

53. Dodds, W.K.; Whiles, M.T. Freshwater Ecology. Concepts and Environmental Applications of Limnology, 2nd ed.; Academic Press: : Cambridge, MA, USA; Elsevier Inc.: Amsterdam, The Netherlands, 2010.

54. Lake, P.S. Drought and aquatic ecosystems. Effects and Responses; Wiley-Blackwell: West Sussex, UK, 2011.

55. McDonough, O.T.; Hosen, J.D.; Palmer, M.A. Temporary streams: The Hydrology, Geography, and Ecology of non-perennially flowing waters. In Rivers Ecosystems: Dynamics, Management and Conservation; Elliot, H.S., Martin, L.E., Eds.; Nova Science Publishers, Inc.: New York, NY, USA, 2011; pp. 259-289.

56. Armstrong, A.; Stedman, R.C.; Bishop, J.A.; Sullivan, P.J. What's a Stream without Water? Disproportionality in Headwater Regions Impacting Water Quality. Environ. Manag. 2012, 50, 849-860. [CrossRef] [PubMed]

57. Gallart, F.; Prat, N.; García-Roger, E.M.; Latron, J.; Rieradevall, M.; Llorens, P.; Barbera, G.G.; Brito, D.; De Girolamo, A.M.; Lo Porto, A.; et al. A novel approach to analysing the regimes of temporary streams in relation to their controls on the composition and structure of aquatic biota. Hydrol. Earth Syst. Sci. 2012, 16, 3165-3182. [CrossRef]

58. Martin, J.; Kurc, S.A.; Zaimes, G.; Crimmins, M.; Hutmacher, A.; Green, D. Elevated air temperatures in riparian ecosystems along ephemeral streams: The role of housing density. J. Arid Environ. 2012, 84, 9-18. [CrossRef]

59. Arthington, A.H.; Bernardo, J.M.; Ilhéu, M. Temporary rivers: Linking Ecohydrology, Ecological Quality and Reconciliation Ecology. River Res. Applic. 2014, 30, 1209-1215. [CrossRef]

60. Boulton, A.J. Conservation of ephemeral streams and their ecosystem services: What are we missing? Aquat. Conserv. 2014, 24, 733-738. [CrossRef] 
61. De Girolamo, A.M.; Gallart, F.; Pappagallo, G.; Santese, G.; Lo Porto, A. An eco-hydrological assessment method for temporary rivers. The Celone and Salsola rivers case study (SE, Italy). Ann. Limnol. Int. J. Lim. 2015, 51, 1-10. [CrossRef]

62. Oueslati, O.; De Girolamo, A.M.; Abouabdillah, A.; Kjeldsen, T.R.; Lo Porto, A. Classifying the flow regimes of Mediterranean streams using multivariate analysis. Hydrol. Process. 2015, 29, 4666-4682. [CrossRef]

63. Moosavi, S. Where the Rivers Run Dry: An Inquiry into the Design of Wadis in the Arabian Peninsula. Ph.D. Thesis, University of Melbourne, Melbourne, Australia, 2016.

64. Datry, T.; Boulton, A.J.; Bonada, N.; Fritz, K.; Leigh, C.; Sauquet, E.; Tockner, K.; Hugueny, B.; Dahm, C.N. Flow intermittence and ecosystem services in rivers of the Anthropocene. J. Appl. Ecol. 2017, 1-12. [CrossRef] [PubMed]

65. DeLucio, J.V.; Múgica, M. Landscape preferences and behaviour of visitors to Spanish national parks. Landsc. Urban. Plan. 1994, 29, 145-160. [CrossRef]

66. García-Llorente, M.; Martín-López, B.; Iniesta-Arandia, I.; López-Santiago, C.A.; Aguilera, P.A.; Montes, C. The role of multi-functionality in social preferences toward semi-arid rural landscapes: An ecosystem service approach. Environ. Sci. Policy 2012, 19-20, 136-146. [CrossRef]

67. Schneider, A.; Jost, A.; Coulon, C.; Silvestre, M.; Thery, S.; Ducharne, A.C.G. Global-scale river network extraction based on high-resolution topography and constrained by lithology, climate, slope, and observed drainage density. Geophys Res. Lett. 2017, 44, 2773-2781. [CrossRef]

68. Gautier, E.F. Sahara: The Great Desert; Octagon Books: New York, NY, USA, 1970.

69. Davies, B.R.; O'Keeffe, J.H.; Snaddon, C.D. A Synthesis of the Ecological Functioning, Conservation and Management of South African River Ecosystems; Water Research Commission Report No. TT62/93; Water Research Commission: Pretoria, South Africa, 1993.

70. Sheldon, F.; Bunn, S.E.; Hughes, J.M.; Arthington, A.H.; Balcombe, S.R.; Fellows, C.S. Ecological roles and threats to aquatic refugia in arid landscapes: Dryland river waterholes. Mar. Freshw. Res. 2010, 61, 885-895. [CrossRef]

71. Snelder, T.H.; Datry, T.; Lamouroux, N.; Larned, S.T.; Sauquet, E.; Pella, H.; Catalogne, C. Regionalization of patterns of flow intermittence from gauging station records. Hydrol. Earth Syst. Sci. 2013, 17, 2685-2699. [CrossRef]

72. Nanson, G.C.; Tooth, S. Arid-zones rivers as indicators of climate change. In Paleoenvironmental Reconstruction in Arid Lands; Singhvi, A.K., Derbyshire, E., Eds.; A.A. Balkema: Rotterdam, The Netherlands, 1999; pp. 175-216.

73. Mateu, J.F. Ríos y ramblas mediterráneos. In Avenidas Fluviales e Inundaciones en la Cuenca del Mediterráneo; Gil Olcina, A., Morales Gil, A., Eds.; Instituto Universitario de Geografía, Universidad de Alicante, Caja de Ahorros del Mediterráneo: Murcia, Spain, 1989; pp. 113-150.

74. Bremner, J.M.; Rogers, J.; Willis, J.P. Sedimentological aspects of the 1988 Orange River floods. Trans. R. Soc. S. Afr. 1990, 47, 247-294. [CrossRef]

75. Reid, I. Sediment dynamics of ephemeral channels. In Dryland Rivers. Hydrology and Geomorphology of Semi-Arid Channels; Bull, L.J., Kirkby, M.J., Eds.; John Wiley \& Sons: Chischester, UK, 2002; pp. 107-128.

76. García, C.; Laronne, J.B.; Sala, M. Variable source areas of bedload flux in a gravel-bed stream. J. Sediment. Res. 1999, 69, 27-31. [CrossRef]

77. Griffin, G.F.; Smith, D.M.S.; Morton, S.R.; Allan, G.E.; Masters, K.A. Status and implications of the invasion of Tamarisk (Tamarix aphylla) on the Finke River, Northern Territory, Australia. J. Environ. Manag. 1989, 29, 297-315.

78. Tooth, S.; Nanson, G.C. The role of vegetation in the formation of anabranching channels in an ephemeral river, Northern Plains, arid central Australia. Hydrol Proc. 2000, 14, 3099-3117. [CrossRef]

79. Jaeger, K.L.; Sutfin, N.A.; Tooth, S.; Michaelides, K.; Singer, M. Geomorphology and sediment regimes of intermittent rivers and ephemeral streams. In Intermittent Rivers and Ephemeral Streams, Ecology and Management; Datry, T., Bonada, N., Boulton, A., Eds.; Academic Press: London, UK, 2017; pp. 21-49.

80. Wolman, M.G.; Gerson, R. Relative scale of time and effectiveness of climate in watershed geomorphology. Earth Surf. Proc. Land 1978, 3, 189-208. [CrossRef]

81. Schumm, S.A. The Fluvial System; John Wiley \& Sons: New York, NY, USA, 1977.

82. Gordon, N.D.; McMahon, T.A.; Finlayson, B.L. Stream Hydrology: An Introduction for Ecologists; John Wiley \& Sons: Chichester, UK, 1993. 
83. Boulton, A.J.; Rolls, R.J.; Jaeger, K.L.; Datry, T. Hydrological connectivity in intermittent rivers and ephemeral streams. In Intermittent Rivers and Ephemeral Streams. Ecology and Management; Datry, T., Bonada, N., Boulton, A., Eds.; Academic Press: London, UK, 2017; pp. 79-108.

84. Nanson, G.C.; Tooth, S.; Knighton, A.D. A global perspective on dryland rivers: Perceptions, misconceptions and distinctions. In Dryland Rivers. Hydrology and Geomorphology of Semi-Arid Channels; John Wiley \& Sons: Chischester, UK, 2002; pp. 17-54.

85. Shannon, J.; Richardson, R.; Thornes, J. Modelling event-based fluxes in ephemeral streams. In Dryland Rivers. Hydrology and Geomorphology of Semi-Arid Channels; Bull, L.J., Kirkby, M.J., Eds.; John Wiley \& Sons: Chischester, UK, 2002; pp. 129-172.

86. Knighton, A.D.; Nanson, G.C. Distinctiveness, diversity and uniqueness in arid zone river systems. In Arid Zone Geomorphology: Process Form and Change in Drylands; Thomas, D.S.G., Ed.; John Wiley \& Sons: Chichester, UK, 1997; pp. 185-203.

87. Larkin, Z.T.; Ralph, T.J.; Tooth, S.; Fryirs, K.A.; Carthey, A.J.R. Identifying threshold responses of Australian dryland rivers to future hydroclimatic change. Sci. Rep. 2020, 10, 6653. [CrossRef] [PubMed]

88. Jenkins, K.M.; Boulton, A.J. Detecting impacts and setting restoration targets in arid-zone rivers: Aquatic micro-invertebrate responses to reduced floodplain inundation. J. Appl. Ecol. 2007, 44, 833-842. [CrossRef]

89. Robson, B.J.; Chester, E.T.; Austin, C.M. Why life history information matters: Drought refuges and macroinvertebrate persistence in non-perennial streams subject to a drier climate. Mar. Freshw. Res. 2011, 62, 801-810. [CrossRef]

90. Stubbington, R.; Datry, T. The macroinvertebrate seedbank promotes community persistence in temporary rivers across climate zones. Freshw. Biol. 2013, 58, 1202-1220. [CrossRef]

91. Pennak, R.W. Freshwater Invertebrates of the United States, 3rd ed.; John Wiley and Sons: New York, NY, USA, 1989.

92. Carvalho, G.H.; Wolf, H.G. Resting eggs of lake Daphnia I. Distribution, abundance and hatching of eggs collected from various depths in lake sediments. Freshw. Biol. 1989, 22, 459-470. [CrossRef]

93. Moritz, C. A note on the hatching and viability of Ceriodaphnia ephippia collected from lake sediment. Hydrobiologia 1987, 145, 309-314. [CrossRef]

94. De Stasio, B.T.J. The seed bank of a freshwater crustacean: Copepodology for the plant ecologist. Ecology 1989, 70, 1377-1389. [CrossRef]

95. Sánchez-Montoya, M.M.; Tockner, K.; von Schiller, D.; Miñano, J.; Catarineu, C.; Lencian, J.L.; Barbera, G.G.; Ruhí, A. Dynamics of ground-dwelling arthropod metacommunities in intermittent streams: The key role of dry riverbeds. Biol. Conserv. 2019. [CrossRef]

96. Wishart, M.J. The terrestrial invertebrate fauna of a temporary stream in southern Africa. Afr. Zool. 2000, 35, 193-200. [CrossRef]

97. Steward, A.L.; Marshall, J.C.; Sheldon, F.; Harch, B.; Choy, S.; Bunn, S.E.; Tockner, K. Terrestrial invertebrates of dry river beds are not simply subsets of riparian assemblages. Aquat. Sci. 2011, 73, 551-566. [CrossRef]

98. Steward, A.L.; Negus, P.; Marshall, J.C.; Clifford, S.E.; Dent, C. Assessing the ecological health of rivers when they are dry. Ecol. Indic. 2018, 85, 537-547. [CrossRef]

99. Corti, R.; Datry, T. Drying of a temperate, intermittent river has little effect on adjacent riparian arthropod communities. Freshw. Biol. 2014, 59, 666-678. [CrossRef]

100. Sánchez-Montoya, M.M.; von Schiller, D.; Ruhí, S.P.G.; Proia, L.; Miñano, J.; Vidal-Abarca, M.R.; Suárez, M.L.; Tockner, K. Responses of ground-dwelling arthropods to surface flow drying in channels and adjacent habitats along Mediterranean streams. Ecohydrology 2016, 9, 1376-1387. [CrossRef]

101. Sánchez-Montoya, M.M.; Guerrero-Brotons, M.; Miñano, J.; Gómez, R. Effects of debris piles and pools along dry riverbeds on nutrients, microbial activity, and ground-dwelling arthropods: A Namibian ephemeral river case. J. Arid Environ. 2019, 175. [CrossRef]

102. Steward, A.L.; Langhans, S.D.; Corti, R.; Datry, T. The biota of intermittent rivers and ephemeral streams: Terrestrial and semiaquatic invertebrates. In Intermittent Rivers and Ephemeral Streams, Ecology and Management; Datry, T., Bonada, N., Boulton, A., Eds.; Academic Press: London, UK, 2017; pp. 245-271.

103. Segev, O.; Ziv, M.; Lubin, Y. The male mating system in a desert widow spider. J. Arachnol. 2003, 31, 379-393. [CrossRef]

104. Crist, T.O.; Guertin, D.S.; Wiens, J.A.; Milne, B.T. Animal movement in heterogeneous landscapes: An experiment with Eleodes beetles in short grass prairie. Funct. Ecol. 1992, 6, 536-544. [CrossRef] 
105. Jopp, F.; Reuter, H. Dispersal of carabid beetles: Emergence of distribution patterns. Ecol. Model. 2005, 186, 389-405. [CrossRef]

106. Sánchez-Montoya, M.M.; Moleón, M.; Sánchez-Zapata, J.A.; Escoriza, D. The biota of intermittent and ephemeral rivers: Amphibians, reptiles, birds and mammals. In Intermittent Rivers and Ephemeral Streams, Ecology and Management; Datry, T., Bonada, N., Boulton, A., Eds.; Academic Press: London, UK, 2017; pp. 299-322.

107. Leggett, K.E.A.; Fennessy, J.; Schneider, S. Seasonal distributions and social dynamics of elephants in the Hoanib River catchment, north-western Namibia. Afr. Zool. 2003, 38, 305-316.

108. Leggett, K.E.A.; Fennessy, J.; Schneider, S. A study of animal movement in the Hoanib River catchment, northwestern Namibia. Afr. Zool. 2004, 39, 1-11.

109. Krueper, D.J. Conservation Priorities in Naturally Fragmented and Human-Altered Riparian Habitats of the Arid West; General Technical Report RM-43; U.S. Department of Agriculture, Cornell Laboratory of Ornithology, Cornell University: Ithaca, NY, USA, 1993.

110. Melton, D.A. The biology of aardvark (Tubulidentata-Orycteropodidae). Mammal Rev. 1976, 6, 75-88. [CrossRef]

111. Haynes, G. Elephants (and extinct relatives) as earth-movers and ecosystem engineers. Geomorphology 2012, 157-158, 99-107. [CrossRef]

112. Ramey, E.M.; Ramey, R.R.; Brown, L.M.; Scott, T.K. Desert elephants (Loxodonta africana) in Namibia dig wells to purify drinking water. Pachyderm 2013, 53, 66-72.

113. Sabater, S.; Timoner, X.; Bornette, G.; de Wilde, M.; Stromberg, J.C.; Stella, J.C. The biota of intermittent rivers and ephemeral streams: Algae and vascular plants. In Intermittent Rivers and Ephemeral Streams, Ecology and Management; Datry, T., Bonada, N., Boulton, A., Eds.; Academic Press: London, UK, 2017; pp. 189-216.

114. Sponseller, R.; Fisher, S. Drainage size, stream intermittency, and ecosystem function in a Sonoran Desert landscape. Ecosystems 2006, 9, 344-356. [CrossRef]

115. Fossati, J.; Pautou, G.; Peltier, J.P. Water as resource and disturbance for wadi vegetation in a hyperarid area (Wadi Sannur, Eastern Desert, Egypt). J. Arid Environ. 1999, 43, 63-77. [CrossRef]

116. Tooth, S.; Nanson, G.C. Anabranching rivers on the Northern Plains of arid central Australia. Geomorphology 1999, 29, 211-233. [CrossRef]

117. Jacobson, P.J.; Jacobson, K.M.; Angermeier, P.L.; Cherry, D.S. Hydrologic influences on soil properties along ephemeral rivers in the Namib Desert. J. Arid Environ. 2000, 45, 21-34. [CrossRef]

118. Jacobson, P.J.; Jacobson, K.M.; Angermeier, P.L.; Cherry, D.S. Variation in material transport and water chemistry along a large ephemeral river in the Namib Desert. Freshw. Biol. 2000, 44, 481-491. [CrossRef]

119. Schaffers, A.P.; Raemaker, I.P.; Sýkora, K.V.; Ter Braak, C.J. Arthropod assemblages are best predicted by plant species composition. Ecology 2008, 89, 782-794. [CrossRef] [PubMed]

120. Dudley, J.P. Seed dispersal of Acacia erioloba by African bush elephants in Hwange National Park, Zimbabwe. Afr. J. Ecol. 1999, 37, 375-385. [CrossRef]

121. Datry, T.; Foulquier, A.; Corti, R.; von Schiller, D.; Tockner, K.; Mendoza-Lera, C.; Clement, J.C.; Gessner, M.O.; Moleón, M.; Stubbington, R.; et al. A global analysis of terrestrial plant litter dynamics in non-perennial waterways. Nat. Geosci. 2018, 11, 497-503. [CrossRef]

122. Shumilova, O.; Zak, D.; Datry, T.; von Schiller, D.; Corti, R.; Foulquier, A.; Obrador, B.; Tockner, K.; Allan, D.C.; Altermatt, F; et al. Simulating rewetting events in intermittent rivers and ephemeral streams: A global analysis of leached nutrients and organic matter. Glob. Chang. Biol. 2019, 1-21. [CrossRef]

123. Keller, P.S.; Catalán, N.; von Schiller, D.; Grossart, H.P.; Koschorreck, M.; Obrador, B.; Frassl, M.A.; Karakaya, N.; Barros, N.; Howitt, J.A.; et al. Global $\mathrm{CO}_{2}$ emissions from dry inland waters share common drivers across ecosystems. Nat. Commun. 2020, 11, 1-8. [CrossRef] [PubMed]

124. Romaní, A.M.; Fischer, H.; Mille-Lindblom, C.; Tranvik, L.J. Interactions of bacteria and fungi on decomposing litter: Differential extracellular enzyme activities. Ecology 2006, 87, 2559-2569. [CrossRef]

125. Ylla, I.; Sanpera-Calbet, I.; Vazquez, E.; Romani, A.M.; Munoz, I.; Butturini, A.; Sabater, S. Organic matter availability during pre- and post-drought periods in a Mediterranean stream. Hydrobiologia 2010, 657, 217-232. [CrossRef]

126. Gallo, M.E.; Porras-Alfaro, A.; Odenbach, K.J.; Sinsabaugh, R.L. Photoacceleration of plant litter decomposition in an arid environment. Soil Biol. Biochem. 2009, 41, 1433-1441. [CrossRef] 
127. Del Campo, R.; Gómez, R. Exposure of wood in floodplains affects its chemical quality and its subsequent breakdown in streams. Sci. Total Environ. 2016, 543, 652-661. [CrossRef] [PubMed]

128. Ortega, M.; Vidal-Abarca, M.R.; Suárez, M.L.; González-Beseran, J.L.; Ramírez-Díaz, L. Caraterísticas físico-químicas de las aguas superficiales de la Rambla del Moro después de una riada (Cuenca del Río Segura, SE de España). Limnética 1988, 4, 19-26.

129. Skoulikidis, N.T.; Amaxidis, Y. Origin and dynamics of dissolved and particulate nutrients in a minimally disturbed Mediterranean river with intermittent flow. J. Hydrol. 2009, 373, 218-229. [CrossRef]

130. Al-Qudah, O.M.; Walton, J.C.; Woocay, A. Chemistry and evolution of desert ephemeral stream runoff. J. Arid Environ. 2015, 122, 169-179. [CrossRef]

131. Von Schiller, D.; Marcé, R.; Obrador, B.; Gómez, L.; Casas, J.P.; Acuña, V.; Koschorreck, M. Carbon dioxide emissions from dry watercourses. Inland Waters 2014, 4, 377-382. [CrossRef]

132. Gómez-Gener, L.; Obrador, B.; Marcé, R.; Acuña, V.; Catalán, N.; Casas-Ruiz, J.P.; Sabater, S.; Muñoz, I.; von Schiller, D. When water vanishes: Magnitude and regulation of carbon dioxide emissions from dry temporary streams. Ecosystems 2016, 19, 710. [CrossRef]

133. Austin, B.J.; Strauss, E.A. Nitrification and denitrification response to varying periods of desiccation and inundation in a western Kansas stream. Hydrobiologia 2011, 658, 183-195. [CrossRef]

134. Arce, M.I.; Sánchez-Montoya, M.M.; Vidal-Abarca, M.R.; Suárez, M.L.; Gómez, R. Implications of flow intermittency on sediment nitrogen availability and processing rates in a Mediterranean head water stream. Aquat. Sci. 2014, 76, 173-186. [CrossRef]

135. Arce, M.I.; Sánchez-Montoya, M.M.; Gómez, R. Nitrogen processing following experimental sediment rewetting in isolated pools in an agricultural stream of a semiarid region. Ecol. Eng. 2015, 77, 233-241. [CrossRef]

136. Merbt, S.N.; Proia, L.; Prosser, J.I.; Marti, E.; Casamayor, E.O.; von Schiller, D. Stream drying drives microbial ammonia oxidation and first-flush nitrate export. Ecology 2016, 97, 2192-2198. [CrossRef]

137. Schimel, J.P. Life in dry soils: Effects of drought on soil microbial communities and processes. Annu. Rev. Ecol. Evol. Syst. 2018, 49, 409-432. [CrossRef]

138. Gionchetta, G.; Oliva, F.; Menéndez, M.; Lopez Laseras, P.; Romaní, A.M. Key role of streambed moisture and flash storms for microbial resistance and resilience to long-term drought. Freshw. Biol. 2019, 64, 306-322. [CrossRef]

139. Costanza, R.; d'Arge, R.; de Groot, R.; Farber, S.; Grasso, M.; Hannon, B.; Limburg, K.; Naeem, S.; Oneill, R.V.; Paruelo, J.; et al. The value of the world's ecosystem services and natural capital. Nature 1997, 387, $253-260$. [CrossRef]

140. Millennium Ecosystem Assessment (MA). Ecosystems and Human Well-Being: Biodiversity Synthesis; World Resources Institute: Washington, DC, USA, 2005.

141. Spanish National Ecosystem Assessment. Ecosystems and Biodiversity for Human Wellbeing. Synthesis of the Key Findings; Biodiversity Foundation of the Spanish Ministry of Agriculture, Food and Environment: Madrid, Spain, 2013. Available online: http://www.ecomilenio.es/ecosystems-and-biodiversity-for-human-wellbeingsnea-synthesis-of-key-findings-download/3661 (accessed on 1 September 2020).

142. Díaz, S.; Demissew, S.; Carabias, J.; Joly, C.; Lonsdale, M.; Ash, N.; Larigauderie, A.; Adhikari, J.R.; Arico, S.; Baldi, A.; et al. The IPBES conceptual framework-Connecting nature and people. Curr. Opin. Environ. Sustain. 2015, 14, 1-16. [CrossRef]

143. De Groot, R.S.; Wilson, M.A.; Boumans, R.M.J. A typology for the classification, description and valuation of ecosystem functions, goods and services. Ecol. Econ. 2002, 41, 393-408. [CrossRef]

144. Powell, D.M.; Brazie, R.; Parsons, A.; Wainwright, J.; Nichols, M. Sediment transfer and storage in dryland headwater streams. Geomorphology 2007, 88, 152-166. [CrossRef]

145. Sánchez, M.A.; Sánchez-Zapata, J.A.; Díez de Revenga, E. El conejo (Oryctolagus cuniculus) en la Región de Murcia. In Actas del II Congreso de la Naturaleza de la Región de Murcia; ANSE, Ed.; ANSE: Murcia, Spain, 2004; pp. 169-179. Available online: https://www.researchgate.net/profile/Jose_Sanchez-Zapata/publication/ 267832938_El_conejo_Oryctolagus_cuniculus_en_la_Region_de_Murcia/links/54dcfae80cf25b09b912e3c0/ El-conejo-Oryctolagus-cuniculus-en-la-Region-de-Murcia.pdf (accessed on 1 September 2020).

146. Salinas, M.J.; Guirado, J. Riparian Plant Restoration in Summer-Dry Riverbeds of Southeastern Spain. Restor. Ecol. 2002, 10, 695-702. [CrossRef] 
147. Burns, R.G.; DeForest, J.L.; Marxsen, J.; Sinsabaugh, R.L.; Stromberger, M.E.; Wallenstein, M.D.; Weintraub, M.N.; Zoppini, A. Soil enzymes in a changing environment: Current knowledge and future directions. Soil Biol. Biochem. 2013, 58, 216-234. [CrossRef]

148. Montes, C.; García, M.R. La Evaluación de los Ecosistemas del Milenio en Andalucía Haciendo Visibles los vínculos entre la Naturaleza y el Bienestar Humano. Junta de Andalucía. 2012. Available online: http://www.juntadeandalucia.es/medioambiente/site/portalweb/menuitem. 7e1cf46ddf59bb227a9ebe205510e1ca/?vgnextoid=de5b4a6acd72f210VgnVCM1000001325e50aRCRD\& vgnextchannel=a349e156217d4310VgnVCM2000000624e50aRCRD (accessed on 27 March 2020).

149. Montes, C.; Santos-Martin, F.; Benayas, J. Ecosistemas y Biodiversidad para el Bienestar Humano. Evaluación de los Ecosistemas del Milenio de España. Fundación Biodiversidad; Ministerio de Medio Ambiente y Medio Rural y Marino: Madrid, Spain, 2011. [CrossRef]

150. UK NEA. The UK National Ecosystem Assessment: Synthesis of the Key Findings; UNEP-WCMC: Cambridge, UK, 2011; Available online: https://www.researchgate.net/publication/317236524_UK_National_Ecosystem_ Assessment_understanding_nature \T1\textquoterights_value_to_society_Synthesis_of_key_findings (accessed on 1 September 2020).

151. Landers, D.H.; Nahlik, A.M. Final Ecosystem Goods and Services Classification System (FEGS-CS)(EPA/600/R-13/ORD-004914); Office of Research and Development, U.S. Environmental Protection Agency: Washington, DC, USA, 2013. Available online: http://refhub.elsevier.com/B978-0-12803835-2.00018-8/rf0255 (accessed on 27 March 2020).

152. Vidal-Abarca, M.R.; Suárez, M.L. Which are, what is their status and what can we expect from ecosystem services provided by Spanish rivers and riparian areas? Biodivers. Conserv. 2013, 22, 2469-2503. [CrossRef]

153. Harrison, P.A.; Vandewalle, M.; Sykes, M.T.; Berry, P.M.; Bugter, R.; de Bello, F.; Feld, C.K.; Grandin, U.; Harrington, R.; Haslett, J.R.; et al. Identifying and prioritising services in European terrestrial and freshwater ecosystems. Biodivers. Conserv. 2010, 19, 2791-2821. [CrossRef]

154. IPBES. Summary for Policymakers of the Regional Assessment Report on Biodiversity and Ecosystem Services for Africa of the Intergovernmental Science-Policy Platform on Biodiversity and Ecosystem Services; Archer, E., Dziba, L.E., Mulongoy, K.J., Maoela, M.A., Walters, M., Eds.; IPBES: Bonn, Germany; IPBES Secretariat: Bonn, Germany, 2018.

155. IPBES. Summary for Policymakers of the Regional Assessment Report on Biodiversity and Ecosystem Services for Asia and the Pacific of the Intergovernmental Science-Policy Platform on Biodiversity and Ecosystem Services; Karki, M., Senaratna Sellamuttu, S., Okayasu, S., Suzuki., W., Eds.; IPBES: Bonn, Germany; IPBES Secretariat: Bonn, Germany, 2018.

156. IPBES. Summary for Policymakers of the Regional Assessment Report on Biodiversity and Ecosystem Services for the Americas of the Intergovernmental Science-Policy Platform on Biodiversity and Ecosystem Services; Rice, J., Seixas, S., Zaccagnini, M.E., Bedoya-Gaitán, M., Valderrama, N., Eds.; IPBES Secretariat: Bonn, Germany, 2018.

157. IPBES. Summary for Policymakers of the Regional Assessment Report on Biodiversity and Ecosystem Services for Europe and Central Asia of the Intergovernmental Science-Policy Platform on Biodiversity and Ecosystem Services; Fischer, M., Rounsevell, M., Torre-Marin, A., Mader, A., Eds.; IPBES Secretariat: Bonn, Germany, 2018.

158. Koundouri, P.; Boulton, A.J.; Datry, T.; Souliotis, I. Ecosystem services, values, and societal perceptions of intermittent rivers and ephemeral streams. In Intermittent Rivers and Ephemeral Streams, Ecology and Management; Datry, T., Bonada, N., Boulton, A., Eds.; Academic Press: London, UK, 2017; pp. 455-476.

159. Shackleton, C.; Shackleton, S.; Gambiza, J.; Nel, E.; Rowntree, K.; Urquhart, P. Links between Ecosystem Services and Poverty Alleviation: Situation Analysis for Arid and Semi-Arid Lands in Southern Africa; Consortium on Ecosystems and Poverty in Sub-Saharan (CEPSA). 2008. Available online: uct.ac.za/sites/default/files/image_tool/images/192/Shackleton\%20et $\% 20 \mathrm{al} \% 20 \% 202008 \%$ 20Southern\%20African\%20Ecosystem\%20Services\%20and\%20Poverty\%20report_CEPSA.pdf (accessed on 1 September 2020).

160. Iniesta-Arandia, I.; García del Amo, D.; García-Nieto, A.P.; Piñeiro, C.; Montes, C.; Martín-López, B. Factors influencing local ecological knowledge maintenance in Mediterranean watersheds: Insights for environmental policies. Ambio 2014, 44, 285-296. [CrossRef]

161. Alkhaddar, R.M. Water harvesting in Jordan using earth ponds. Waterlines 2003, 22, 19-21. [CrossRef]

162. Nasiri, F.; Mafakheri, M.S. Qanat water supply systems: A revisit of sustainability perspectives. Environ. Syst. Res. 2015, 4, 13. [CrossRef] 
163. Seely, M.; Henderson, J.; Heyns, P.; Jacobson, P.; Nakale, T.; Nantanga, K.; Schachtschneider, K. Ephemeral and endoreic river systems: Relevance and management challenges. In Transboundary Rivers, Sovereignty and Development: Hydropolitical Drivers in the Okavango River Basin; Turton, A., Ashton, P., Cloete, E., Eds.; African Water Issues Research Unit: Pretoria, South Africa, 2003; pp. 187-212.

164. Ito, A. Distribution of the Nara plant that affect the life of the Topnaar people in the lower Kuiseb River, Namib Desert. Afr. Study Monogr. Suppl. 2005, 30, 65-75.

165. Ffolliott, P.F.; DeBano, L.F. Riparian Areas of the Southwestern United States: Hydrology, Ecology, and Management; CRC Press: Boca Raton, FL, USA, 2003.

166. Mizuno, K.; Yamagata, K. Vegetation succession and plant use in relation to environmental changes along the Kuiseb River in the Namib Desert. Afr. Study Monogr. 2005, 30, 3-14. [CrossRef]

167. Yamagata, K. Recent grain-size coarsening of floodplain deposits and forest decline along the Kuiseb River, Namib Desert, Namibia. Afr. Study Monogr. 2010, 40, 19-30.

168. Jacobson, P.J.; Jacobson, K.M. Hydrologic controls of physical and ecological processes in Namib Desert ephemeral rivers: Implications for conservation and management. J. Arid Environ. 2013, 93, 80-93. [CrossRef]

169. Bond, N.R.; Cottingham, P. Ecology and Hydrology of Temporary Streams: Implications for Sustainable Water Management; eWater Technical Report; eWater Cooperative Research Centre: Canberra, Australia, 2008; Available online: https://www.researchgate.net/profile/Nick_Bond2/publication/242107251_Ecology_ and_Hydrology_of_Temporary_Streams_Implications_for_Sustainable_Water_Management/links/ 548b83780cf214269f1dd657/Ecology-and-Hydrology-of-Temporary-Streams-Implications-for-SustainableWater-Management.pdf (accessed on 1 September 2020).

170. Hassan, M.A.; Egozi, R. Impact of wastewater discharge on the channel morphology of ephemeral streams. Earth Surf. Proc. Land. 2001, 26, 1285-1302. [CrossRef]

171. Skoulikidis, N.T.; Sabater, S.; Datry, T.; Morais, M.M.; Buffagni, A.; Dörflinger, G.; Zogaris, S.; Sánchez-Montoya, M.M.; Bonada, N.; Kalogianni, E.; et al. Non-perennial Mediterranean rivers in Europe: Status, pressures, and challenges for research and management. Sci. Total Environ. 2017, 577, 1-18. [CrossRef]

172. National Research Council. Riparian Areas: Functions and Strategies for Management; The National Academies Press: Washington, DC, USA, 2002. [CrossRef]

173. Krueper, D.J. Effects of livestock management on Southwestern riparian ecosystems. In Shaw DW, Finch DM (Tech. Coords) Desired Future Conditions for Southwestern Riparian Ecosystems: Bringing Interests and Concerns Together. Gen. Tech. Rep. RM-GTR-272; US Department of Agriculture, Forest Service, Rocky Mountain Forest and Range Experiment Station: Fort Collins, CO, USA, 1996; pp. 281-301.

174. Maldonado, M.B.; Aranibar, J.N.; Serrano, A.M.; Chacoff, N.P.; Vázquez, D.P. Dung beetles and nutrient cycling in a dryland environment. Catena 2019, 179, 66-73. [CrossRef]

175. Zaragoza, E.B. Anthropic occupation of ravines and gullies in the Bajo Segura county (Alicante): Analysis and diagnosis of the situation in some of its towns. Investig. Geogr. 1997, 17, 149-162. [CrossRef]

176. Sánchez-Montoya, M.M.; Moleón, M.; Sánchez-Zapata, J.A.; Tockner, K. Dry riverbeds: Corridors for terrestrial vertebrates. Ecosphere 2016, 7, e01508. [CrossRef]

177. Chiu, M.C.; Leigh, C.; Mazor, R.; Cid, N.; Resh, V. Anthropogenic threats to intermittent rivers and ephemeral streams. In Intermittent Rivers and Ephemeral Streams, Ecology and Management; Datry, T., Bonada, N., Boulton, A., Eds.; Academic Press: London, UK, 2017; pp. 433-454.

178. Milton, S.J.; Dean, W.R.J. Plant invasions in arid areas: Special problems and solutions: A South African perspective. Biol. Invasions 2010, 12, 3935-3948. [CrossRef]

179. Coffman, G.C. Factors Influencing Invasion of Giant Reed (Arundo donax) in Riparian Ecosystems of Mediterranean-Type Climate Regions. Ph.D. Thesis, University of California, Los Angeles, CA, USA, 2007. [CrossRef]

180. Norström, A.V.; Cvitanovic, C.; Löf, M.F.; West, S.; Wyborn, C.; Balvanera, P.; Bednarek, A.T.; Bennett, E.M.; Biggs, R.; de Bremond, A.; et al. Principles for knowledge co-production in sustainability research. IJEWE 2020, 3. [CrossRef]

181. Hall, C.M.; Boyd, S.W. Nature-Based Tourism in Peripheral Areas: Development or Disaster? Channel View Publications: Bristol, UK, 2005; Volume 21. 
182. Stubbington, R.; Chadd, R.; Cid, N.; Csabai, Z.; Miliša, M.; Morais, M.; Munné, A.; Pařil, P.; Pešić, V.; Tziortzis, I.; et al. Biomonitoring of intermittent rivers and ephemeral streams in Europe: Current practice and priorities to enhance ecological status assessments. Sci. Total Environ. 2018, 618, 1096-1113. [CrossRef] [PubMed]

183. Ollero, A.; Ballarín, D.; Díaz Bea, E.; Mora, D.; Sánchez Fabre, M.; Acín, V.; Echeverría, M.T.; Granado, D.; González de Matauco, A.I.; Sánchez, L.; et al. IHG: Un índice para la valoración hidrogeomorfológica de sistemas fluviales. Limnetica 2008, 27, 171-188. [CrossRef]

184. Suarez, M.L.; Vidal-Abarca, M.R. Índice para valorar el estado de conservación de las ramblas mediterráneas (Índice de alteración de ramblas, IAR). Tecnol. Agua 2008, 293, 67-78.

185. Suárez, M.L.; Vidal-Abarca, M.R.; Navarro, I.; Gómez, R.; López-Bermúdez, F. Los arroyos de Baja California Sur (México): Caracterización ambiental y aplicación de un índice de Estado de Alteración (IAR). C y G 2010, 24, 63-77.

(C) 2020 by the authors. Licensee MDPI, Basel, Switzerland. This article is an open access article distributed under the terms and conditions of the Creative Commons Attribution (CC BY) license (http://creativecommons.org/licenses/by/4.0/). 